\title{
ECONOMICS
}

\section{ECONOMIC GROWTH AND EVOLUTION: PARENTAL PREFERENCE FOR QUALITY AND QUANTITY OF OFFSPRING}

by

\section{Jason Collins}

Business School

The University of Western Australia

and

Boris Baer

Plant Energy Biology

ARC Centre of Excellence

The University of Western Australia

and

Ernst Juerg Weber

Business School

The University of Western Australia 


\title{
ECONOMIC GROWTH AND EVOLUTION: PARENTAL PREFERENCE FOR QUALITY AND QUANTITY OF OFFSPRING
}

\author{
by \\ Jason Collins \\ The Business School \\ University of Western Australia \\ and \\ Boris Baer \\ Plant Energy Biology \\ ARC Centre of Excellence \\ The University of Western Australia \\ and \\ Ernst Juerg Weber \\ Business School \\ The University of Western Australia
}

Draft version: 5 May 2011

DISCUSSION PAPER 11.05

\section{Abstract}

This paper presents a quantitative analysis of the model developed in Galor and Moav, Natural Selection and the Origin of Economic Growth (2002), in which agents vary genetically in their preference for quality and quantity of children. We simulate a parametric form of the model, enabling examination of the transition from Malthusian stagnation to modern rates of economic growth. The simulations allow an assessment of the strength of the biological foundations of the model and demonstrate the susceptibility of the modern high-growth state to invasion by cheaters. Extending the model from two to three genotypes suggests the possibility of a return to Malthusian conditions rather than a permanent state of modern growth.

Key words: Evolution, Growth, Natural selection, Education, Human capital

For their comments, we thank participants in seminars with the University of Western Australia economics discipline, UWA Centre for Evolutionary Biology and ETH Zurich experimental ecology and theoretical biology groups. 


\section{Introduction}

Over the past thirty years, there has been an increasing scientific interest in using evolutionary theory to explain human economic behaviour. Since the advocacy of this approach by Becker (1976) and Hirshleifer (1977), Darwinian (1859) thinking has been used to explain the evolution of human risk preference (Rubin \& Paul II 1979), time preference (Hansson \& Stuart 1990, Rogers 1994, Robson \& Samuelson 2007, Robson $\&$ Szentes 2008), and the shape of utility functions (Netzer 2009). ${ }^{1}$ More recently, evolutionary theory has been applied to the emergence of modern economic growth.

Galor and Moav (2002) developed a unified growth model in which natural selection favours traits that affect the economic environment. This model was the first to use frequency changes of heritable traits to explain the shift of human populations from Malthusian stagnation to modern economic growth. Galor and Moav proposed a geneencoded preference for quality or quantity of children, which is similar to $r / K$ selection in behavioural ecology. The quantity-quality trade-off has been hypothesised as an economic factor by, among others, Becker (1960), and Becker and Lewis (1974). Becker et al. (1990) considered the link between the quantity-quality trade-off and economic growth. ${ }^{2}$

In the Galor and Moav model, individuals who invest in the education of their children have an evolutionary advantage in the early stages of economic development. As technological progress depends on human capital and the returns to education increase with technological progress, this positive feedback ultimately results in an escape from Malthusian stagnation. Galor and Moav noted that natural selection might favour other growth promoting traits. For example, Galor and Michalopoulos (2011) suggested that entrepreneurial spirit creates an evolutionary advantage in the early stages of economic development, while less entrepreneurially spirited individuals do well in mature economies. The positive feedback between entrepreneurial spirit and economic development lifts the economy out of Malthusian stagnation.

\footnotetext{
${ }^{1}$ Alchian (1950) and Nelson and Winter (1982) applied evolutionary concepts to the theory of firm and industrial organization.

${ }^{2}$ Increasing technological progress and variation in heritable preferences underlies the trade-off in the Galor and Moav model, while a substitution effect due to higher income drives the trade-off proposed by Becker at al.
} 
Galore and Moav (2002) investigated the dynamics of their model analytically using phase diagrams. In this paper, their model is analysed numerically by simulation. The method is similar to the one that Lagerlof (2006) used to simulate the model of Galor and Weil (2000). ${ }^{3}$ The advantage of simulation is that it allows exploration of a richer specification of models for which there exists no closed-form solution. In particular, it will be possible to consider more than two genotypes with different preference for quality and quantity of children, which may emerge either though migration or mutation. This allows a demonstration of the susceptibility of the modern high-growth state to invasion by cheaters. The extended model suggests the possibility of a return to Malthusian conditions after the modern period of economic growth rather than a permanent continuation of growth.

\section{Background}

Besides Galor and Moav (2002), several other authors applied evolutionary theory in the analysis of economic growth and the transition from the Malthusian state to modern rates of growth. In their seminal paper on the evolution of preferences for saving and labour supply, Hansson and Stuart (1990) proposed that human preferences depend on the availability of resources. Harsh natural environments select for genotypes that have a stronger preference for saving, leading to an equilibrium with low population density and high per-capita capital. Selected traits include a preference for work and accumulation of physical capital. This might explain why humans left the Malthusian state first in regions with harsh winters.

Clark (2007) suggested that selection for certain heritable characteristics accounted for the Industrial Revolution. While open as to whether these traits were transmitted genetically or culturally, he found higher reproductive success among wealthy males in England between 1250 and $1800 .^{4}$ He hypothesised that individuals with favoured traits such as a propensity to hard work and saving increased in frequency during this time.

\footnotetext{
${ }^{3}$ The trigger for the take-off in the Galor and Weil (2000) model is increasing technological progress with increasing population, while the Galor and Moav (2002) model relies on investment in education by the quality-preferring types in the population.

${ }^{4}$ Clark's proposal followed from work published by Clark and Hamilton (2006) on the reproductive success of the wealthy in England.
} 
This change in population composition could then have provided the basis for the Industrial Revolution.

The increasing availability of population genetic data, such as Cavalli-Sforza et al. (1994), has led to more research. Spolaore and Wacziarg (2009) linked differences in economic development with the genetic distance between populations, which depends on the time elapsed since two populations shared a common ancestor. They proposed that genetic distance increases income differences because it may act as a barrier to the diffusion of technological development between populations. As genetic distance is based on neutral genes that are not subject to selection pressure, their hypothesis does not rely on any difference in economic traits between populations. Differences in income may arise merely by chance and the failure of technological advances to diffuse through the genetic distance barrier.

Recently, Ashraf and Galor (2010) proposed that the geographic distance of a population from Africa has affected the level of growth and development across regions. They found that populations with elevated or reduced genetic diversity have experienced the lowest level of economic development since the Industrial Revolution. ${ }^{5}$ Indigenous populations of the Americas have the lowest level of genetic diversity due to the founder effect, whereas Africans have the highest. ${ }^{6}$ The hump-shaped relationship between genetic diversity and economic development is due to a trade-off between the costs and benefits of genetic diversity. A high level of genetic diversity expands the production possibilities through complementarities in knowledge production but disrupts the diffusion of technology due to lower levels of trust and cooperation between dissimilar individuals.

\section{The Galor and Moav model}

Galor and Moav (2002) developed an overlapping generations model, with each agent living for two periods (childhood and adulthood). In childhood, agents are passive and

\footnotetext{
${ }^{5}$ Genetic diversity was measured using expected heterozygosity, an index of the probability that two individuals, selected at random from the relevant population, are genetically different from one another.

${ }^{6}$ The founder effect is the loss of genetic diversity that occurs when a small subset of a larger population establishes a new population.
} 
they receive education. During adulthood, agents decide on how much time to dedicate to work or childrearing and they choose the number of children and their education. Reproduction is asexual by a single parent.

Production in the economy occurs with inputs of labour, $H_{t}$, and a limited resource, $X$, which may be called land. $H_{t}$ measures the aggregate quantity of efficiency units of labour at time $t$. Aggregate output, $Y_{t}$, is given by a constant returns to scale technology:

$$
Y_{t}=H_{t}^{1-\alpha}\left(A_{t} X\right)^{\alpha} \quad \alpha \in(0,1)
$$

1- $\alpha$ is the labour share of production. The level of technology, $A_{t}$, is determined endogenously in the model.

Assuming there are no property rights over land, the return to land is zero and the wage per efficiency unit of labour, $w_{t}$, is the output per unit of labour, $x_{t}$.

$$
w_{t}=x_{t}^{\alpha}
$$

where $x_{t}=\frac{A_{t} X}{H_{t}}$

The population consists of two genotypes $(i=a, b)$ with different preferences between the quality and quantity of their children. The utility function is:

$$
\begin{aligned}
& u_{t}^{i}=(1-\gamma) \ln c_{t}^{i}+\gamma\left[\ln n_{t}^{i}+\beta^{i} \ln h_{t+1}^{i}\right] \\
& \gamma \in(0,1) ; \quad \beta^{i} \in(0,1] ; \quad i \in a, b
\end{aligned}
$$

where $c_{t}^{i}$ is the consumption of an individual with genotype $i$ in period $t, n_{t}^{i}$ is the number of children, and $h_{t+1}^{i}$ is the level of human capital of each child. The parameter $\gamma$ measures the relative weight of children in the utility function, and the parameter $\beta^{i}$ determines the weight that a genotype $i$ individual gives to the quality of children. Both parameters are inherited without change by the subsequent generations.

In adulthood, agents have one unit of time that they allocate between childrearing and participation in the labour market. Potential income, $z_{t}^{i}$, is the maximum income that could be earned if the agent's entire time endowment was devoted to labour force participation:

$$
z_{t}^{i}=w_{t} h_{t}^{i}=x_{t}^{\alpha} h_{t}^{i}
$$


A parent incurs a base time cost, $\tau$, for each child, with an additional time cost to educate the child to the level of education $e_{t+1}^{i} \cdot n_{t}^{i}\left(\tau+e_{t+1}^{i}\right)$ is the total cost of raising a family with $n$ children and $1-n_{t}^{i}\left(\tau+e_{t+1}^{i}\right)$ is the time left for working. Thus, the budget constraint faced in adulthood is:

$$
c_{t}^{i} \leq w_{t} h_{t}^{i}\left(1-n_{t}^{i}\left(\tau+e_{t+1}^{i}\right)\right)
$$

Human capital is a function of education and the technological environment. Education increases human capital, while technological progress reduces the usefulness of existing human capital. The function for human capital and the conditions it must satisfy are as follows:

$$
\begin{array}{ll}
h_{t+1}^{i}=h\left(e_{t+1}^{i}, g_{t+1}\right) & g_{t+1} \equiv\left(A_{t+1}-A_{t}\right) / A_{t} \\
h_{e}\left(e_{t+1}^{i}, g_{t+1}\right)>0 & h_{e e}\left(e_{t+1}^{i}, g_{t+1}\right)<0 \\
h_{g}\left(e_{t+1}^{i}, g_{t+1}\right)<0 & h_{g g}\left(e_{t+1}^{i}, g_{t+1}\right)>0 \\
h_{e g}\left(e_{t+1}^{i}, g_{t+1}\right)>0 & h(0,0)=1 \\
\lim _{g \rightarrow \infty} h\left(0, g_{t+1}\right)=0 &
\end{array}
$$

Human capital increases at a diminishing rate with education $\left(e_{t+1}^{i}\right)$, it is eroded at a decreasing rate by technological progress $\left(g_{t+1}\right)$, and technological progress strengthens the effect of education on human capital. Human capital is normalised to one in the absence of education and technological progress.

Substituting equations (5) and (6) into equation (3), a genotype $i$ parent of generation $t$ faces the following optimisation problem:

$$
\begin{gathered}
\left\{n_{t}^{i}, e_{t+1}^{i}\right\}=\operatorname{argmax}\left\{(1-\gamma) \ln w_{t} h_{t}^{i}\left[1-n_{t}^{i}\left(\tau+e_{t+1}^{i}\right)\right]\right. \\
\left.+\gamma\left[\ln n_{t}^{i}+\beta^{i} \ln h\left(e_{t+1}^{i}, g_{t+1}\right)\right]\right\}
\end{gathered}
$$

subject to income being enough to meet the subsistence level of consumption $\tilde{c}$.

$$
\begin{aligned}
& w_{t} h_{t}^{i}\left[1-n_{t}^{i}\left(\tau+e_{t+1}^{i}\right)\right] \geq \tilde{c} \\
& \left(n_{t}^{i}, e_{t+1}^{i}\right) \geq 0
\end{aligned}
$$


The fertility of a genotype $i$ individual varies across three scenarios: where the subsistence constraint does not bind, where it binds, and where potential income is insufficient to meet the subsistence level of consumption. Taking the first order condition of equation (7) with respect to $n_{t}^{i}$ gives fertility when the constraint does not bind; solving equation (8) as an equality gives fertility where the constraint binds; and no children are born when the parent is reduced to the subsistence level of consumption. These three scenarios are shown in equation (9):

$$
n_{t}^{i}=\left\{\begin{array}{cc}
\frac{\gamma}{\tau+e_{t+1}^{i}} & \text { if } z_{t}^{i} \geq \tilde{z} \\
\frac{1-\tilde{c} / z_{t}^{i}}{\tau+e_{t+1}^{i}} & \text { if } \tilde{c} \leq z_{t}^{i} \leq \tilde{z} \\
0 & \text { if } z_{t}^{i} \leq \tilde{c}
\end{array}\right.
$$

where $\tilde{z} \equiv \frac{\widetilde{c}}{(1-\gamma)}$

The number of children depends positively on potential income and negatively on the time cost of childrearing. Above the critical value $\tilde{z}$, only the time costs of childrearing matter. No children are born when the parent is reduced to the subsistence level of consumption.

Taking the first-order condition of equation (7) with respect to the second choice variable $e_{t+1}$ gives:

$$
\beta^{i} h_{e}\left(e_{t+1}^{i}, g_{t+1}\right)-\frac{h\left(e_{t+1}^{i}, g_{t+1}\right)}{\left(\tau+e_{t+1}^{i}\right)}\left\{\begin{array}{l}
=0 \text { if } e>0 \\
\leq 0 \text { if } e=0
\end{array}\right.
$$

The first term represents the utility benefit of a marginal increase in investment in the quality of children. The utility benefit of education depends positively on the partial derivative of the human capital function $h_{e}$ and the weight given to the quality of children in the utility function $\beta$. The second term is the utility benefit of a marginal increase in investment in the quantity of children. Optimal behaviour requires that the marginal benefit of education equals the marginal benefit of additional children if the parent chooses a positive level of education.

The following condition ensures that the level of education is positive for those with the highest valuation for quality $\left(\beta^{i}=1\right)$ when technological progress is zero:

$$
h_{e}(0,0)>\frac{1}{\tau}
$$


If equation (11) is not satisfied, no agents will educate their children, leading to a permanent Malthusian state.

The average level of education in the population, $e_{t}$, is:

$$
\begin{aligned}
& e_{t}=q_{t} e_{t}^{a}+\left(1-q_{t}\right) e_{t}^{b} \\
& q_{t}=\frac{L_{t}^{a}}{L_{t}^{a}+L_{t}^{b}}=\frac{L_{t}^{a}}{L_{t}}
\end{aligned}
$$

$q_{t}$ indicates the proportion of genotype $a$ in the population, with $L_{t}^{a}$ and $L_{t}^{b}$ the number of genotype $a$ and $b$ individuals and $L_{t}$ the total population. It is assumed that technological progress, $g_{t+1}$, which determines economic growth, is an increasing and concave function of the average level of education:

$$
\begin{aligned}
& g_{t+1} \equiv\left(A_{t+1}-A_{t}\right) / A_{t}=\varphi\left(e_{t}\right) \\
& \varphi_{e}>0 ; \quad \varphi_{e e}<0 ; \quad \varphi(0)=0
\end{aligned}
$$

Finally, the following steps yield the aggregate labour supply function. The number of efficiency units of labour supplied by the population is:

$$
H_{t}=L_{t}^{a} f_{t}^{a} h_{t}^{a}+L_{t}^{b} f_{t}^{b} h_{t}^{b}=L_{t}\left(q_{t} f_{t}^{a} h_{t}^{a}+\left(1-q_{t}\right) f_{t}^{b} h_{t}^{b}\right)
$$

where $f_{t}^{i}$ is the fraction of time used by genotype $i$ for labour:

$$
f_{t}^{i}=\left\{\begin{array}{lr}
1-\gamma & \text { if } z_{t}^{i} \geq \tilde{z} \\
\tilde{c} / z_{t}^{i} & \text { if } \tilde{c} \geq z_{t}^{i} \leq \tilde{z}
\end{array}\right.
$$

Equation (15) reflects the growing allocation of time to child rearing when potential income increases. When income reaches the critical value $\tilde{z}$, the fraction of time used for child rearing reaches a maximum of $\gamma$, leaving the fraction $(1-\gamma)$ for labour.

Using equations (14) and (15), the aggregate labour supply is:

$$
\begin{gathered}
H_{t}=\left\{\begin{array}{cr}
L_{t}(1-\gamma)\left(q_{t} h_{t}^{a}+\left(1-q_{t}\right) h_{t}^{b}\right) & \text { if } z_{t}^{a} \geq \tilde{z} \text { and } z_{t}^{b} \geq \tilde{z} \\
L_{t}\left(q_{t}(1-\gamma) h_{t}^{a}+\left(1-q_{t}\right)\left(\tilde{c} / z_{t}^{b}\right) h_{t}^{b}\right) & \text { if } z_{t}^{a} \geq \tilde{z} \text { and } \tilde{c} \leq z_{t}^{b} \leq \tilde{z} \\
L_{t}\left(q_{t}\left(\tilde{c} / z_{t}^{a}\right) h_{t}^{a}+\left(1-q_{t}\right)\left(\tilde{c} / z_{t}^{b}\right) h_{t}^{b}\right) & \text { if } \tilde{c} \leq z_{t}^{a} \leq \tilde{z} \text { and } \tilde{c} \leq z_{t}^{b} \leq \tilde{z}
\end{array}\right\} \\
\equiv H\left(L_{t}^{a}, L_{t}^{b}, e_{t}^{a}, e_{t}^{b}, g_{t}, z_{t}^{a}, z_{t}^{b}\right)
\end{gathered}
$$




\section{Response curves}

Despite each genotype having a fixed preference for quality, this does not result in a fixed level of investment in education over time as the return to education changes with the rate of technological progress. However, the agents' education response curve to the rate of technological progress is fixed. Figure 1 shows how much time each genotype invests into education at a given level of technological progress, with the quality-preferring genotype $a$ investing more in education at all rates of technological progress. The shape of the response curves is based on simulations of the model in section $8 .^{7}$ The inequality (11) guarantees that quality-preferring genotype $a$ parents always choose a positive level of education for their children.

Figure 1: Education response curves

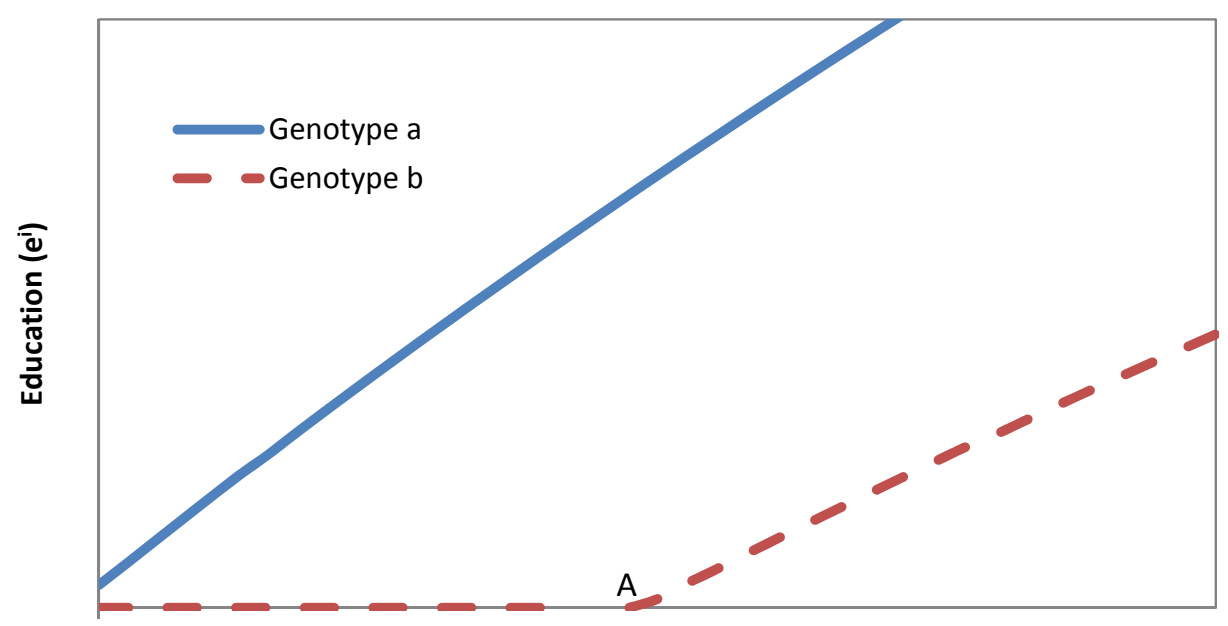

Technological progress (g)

The fitness of a genotype depends on the number of offspring, which determines its prevalence in the population over time. Which genotype has more children in turn depends on the level of technology and economic growth. In the Malthusian state, the

\footnotetext{
${ }^{7}$ The slope of the education response curve can be derived by applying the implicit function rule to equation (10). Using $F(e, g)=\beta h_{e}-\frac{h(e, g)}{\tau+e}=0$$$
\frac{d e}{d g}=-\frac{F_{g}}{F_{e}}=-\frac{\beta^{i} h_{e g}\left(\tau+e_{t+1}^{i}\right)-h_{g}}{\beta^{i} h_{e e}\left(\tau+e_{t+1}^{i}\right)-h_{e}+\frac{h}{\left(\tau+e_{t+1}^{i}\right)}}
$$

The education response curve slopes upward if: $-\beta^{i} h_{e e}\left(\tau+e_{t+1}^{i}\right)+h_{e}>\frac{h}{\left(\tau+e_{t+1}^{i}\right)}$
} 
quality-preferring genotype has more children because education increases human capital and potential income. The rise in the prevalence of the quality-preferring genotype underpins slow technological progress in the Malthusian state. The rate of technological progress gradually increases until a threshold is reached at which it becomes worthwhile for the quantity-preferring genotype to invest in education. This threshold is given by point $\mathrm{A}$ in Figure 1. This positive feedback leads to an acceleration of technological progress and economic growth, putting an end to Malthusian stagnation.

When potential income exceeds the critical value $\tilde{z}$ for both genotypes, they both will invest the same proportion of time into raising children. However, since $h_{g}<0$, the technological progress degrades human capital, which makes it costly for the qualitypreferring genotype to maintain the high level of human capital of its children. For this reason, the quantity-preferring genotype gains an evolutionary advantage during the period of economic growth that follows the Malthusian state.

Figure 2 shows the number of children of each genotype as a function of output per efficiency unit of labour, $x_{t}$, which is equal to the wage per unit of human capital. The fertility response curves are based on the optimum conditions in equation (9) and the definition of potential income in equation (4). The quality-preferring genotype can procreate at a lower level of $x_{t}$ than the quantity-preferring genotype. Figure 2 illustrates the reversal in relative fitness of genotypes that occurs during economic development.

Figure 2: Fertility response curves

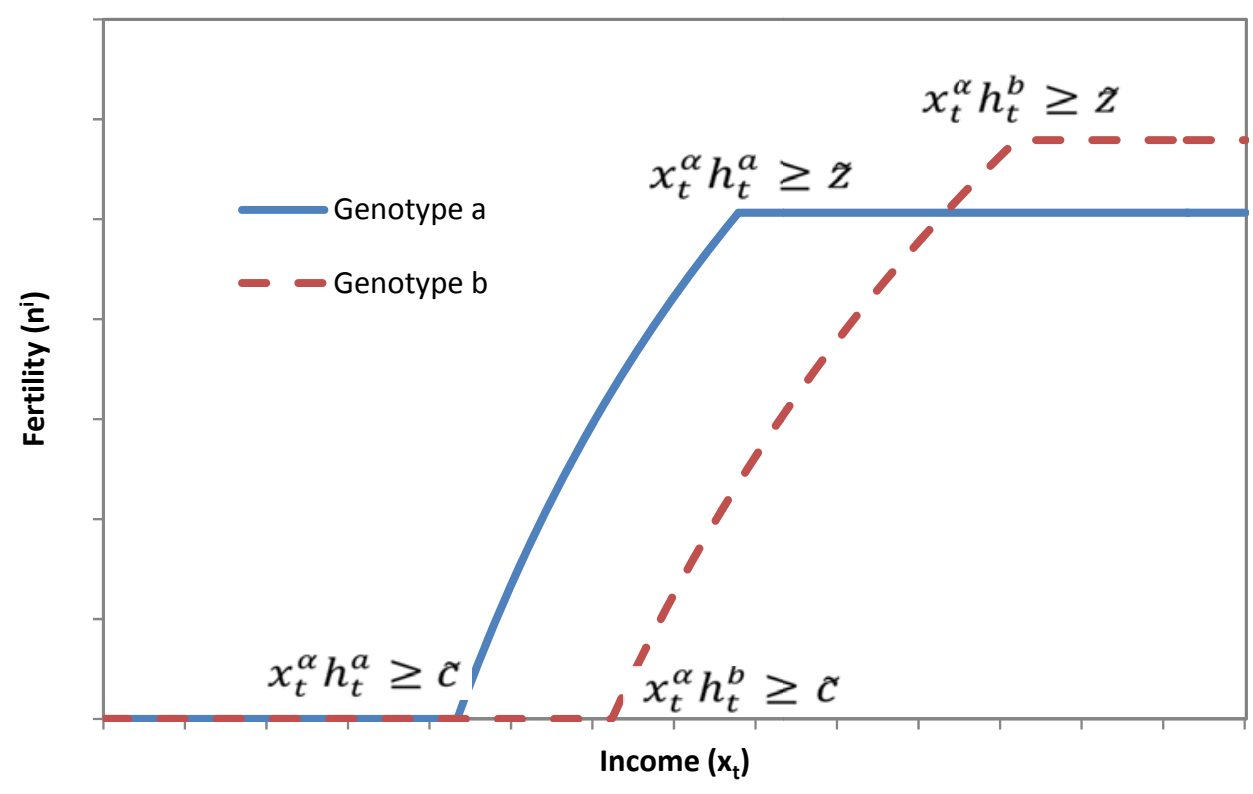


The higher fitness of the quality-preferring genotype in the Malthusian state and the quantity-preferring type in the modern growth state is akin to the classical $r / K$ selection theory in evolutionary biology. Individuals that use the $r$ strategy produce many offspring, each of which has a low probability of surviving to adulthood, while $K$ strategists produce fewer offspring in which they invest more heavily, giving them a higher probability of surviving to adulthood. ${ }^{8} r$ strategists exploit less crowded ecological niches, while $K$ strategists are favoured in more crowded environments. This behaviour occurs in the Galor and Moav model. In the Malthusian state, where resources are scarce and the economy is effectively crowded, the quality-preferring genotype has higher fitness. In the modern growth regime, the economy has become uncrowded, giving higher fitness to the quantity-preferring genotype.

The education and fertility response functions in Figures 1 and 2 allow limited phenotypic plasticity in the form of varying the level of education in response to technological progress. However, there is no flexibility in other dimensions. In particular, there is no fine-tuning of the response to economic growth to optimise fitness. In the modern growth era, quality-preferring parents engage in a self-defeating strategy of overeducating their children that affects their fitness. Additional flexibility in the education response could materially affect model predictions.

\section{Functional forms}

To simulate the model, functional forms for $h_{t+1}^{i}$ and $g_{t+1}$ are needed. The following function for $h_{t+1}^{i}$ matches most of the requirements given in equation (6):

$$
h_{t+1}^{i}=h\left(e_{t+1}^{i}, g_{t+1}\right)=\frac{m e_{t+1}+a}{e_{t+1}+r g_{t+1}+a}
$$

This function does not fulfil the condition that $h_{e g}>0$ for all values of $e_{t+1}^{i}$ and $g_{t+1}$, but this is only a sufficient and not a necessary condition. Simulating the model of Galor and Weil, Lagerlof (2004) uses a similar functional form, with $m=r=1$. Defining $a=\rho \tau ; \rho \in(0,1)$, Lagerlof interpreted the parameter $\rho$ as the portion of fixed time cost

\footnotetext{
${ }^{8}$ In relation to other species, human reproductive strategy of even the quantity-preferring type would be described as strongly $K$. There is considerable debate in the literature as to the appropriateness of applying $r / K$ selection theory within the human species (for example, see Graves (2002)).
} 
of childrearing that contributes towards the development of the base level of human capital.

The parameter $m$ is included in equation (17) to allow the condition in equation (11) to be met. Using Lagerlof's definition of $a=\rho \tau, m$ must be bigger than 1 .

$$
m>\frac{a}{\tau}+1=\rho+1
$$

This condition ensures that a quality-preferring genotype with $\beta^{a}=1$ will invest in education when there is no economic growth. The parameter $r$ is selected produce modern rates of education and economic growth. ${ }^{9}$

A simple functional form for equation (13) is the power function:

$$
g_{t+1}=k e_{t}^{d} ; \quad 0<\mathrm{d}<1 ; \mathrm{k}>0
$$

Using equations (10) and (17), the level of education that each genotype gives to its children is:

$$
\begin{aligned}
& e_{t+1}^{i}=\max \left\{0, \quad \frac{1}{2 m}\left(\left(m\left(B^{i}-1\right)\left(r g_{t+1}+a\right)-a\left(B^{i}+1\right)\right)+\right.\right. \\
& \left.\left.\sqrt{\left(m\left(B^{i}-1\right)\left(r g_{t+1}+a\right)-a\left(B^{i}+1\right)\right)^{2}+4 m\left(\left(m B^{i} \tau-a\right)\left(r g_{t+1}+a\right)-a B^{i} \tau\right)}\right)\right\} \\
& \equiv \varphi^{i}\left(e_{t}\right)
\end{aligned}
$$

This equation indicates that education in period $t+1$ is a function of the rate of technological progress in period $t+1$, which in turn is a function of the average level of education in period $t$. This link between education in one period and the next is crucial for the transition out of the Malthusian state.

\footnotetext{
${ }^{9}$ The parameter $a$ could also be used for this purpose, but reducing $a$ tends to increase perturbations and increase the instability of the model.
} 


\section{The dynamical system}

The dynamics of the system can be captured in a system of six difference equations that describe the behaviour of the endogenous variables $A_{t}, g_{t}, e_{t}^{a}, e_{t}^{b}, L_{t}^{a}$ and $L_{t}^{b}$. Before defining these equations, $z_{t}^{i}$ and $n_{t}^{i}$ must be expressed in terms of the endogenous variables.

Collecting equations (2), (4), (16) and (17), potential income per worker equals:

$$
z_{t}^{i}=w_{t} h_{t}^{i}=\left(\frac{A_{t} X}{H_{t}}\right)^{\alpha}\left(\frac{m e_{t}^{i}+a}{e_{t}^{i}+r g_{t}+a}\right)
$$

As $H_{t}$ is a function of $z_{t}^{i}$, equation (21) needs to be solved by iteration. The relationship between $H_{t}$ and $z_{t}^{i}$ magnifies population perturbations during the Malthusian era. ${ }^{10}$ The model is modified at this stage in order to avoid extinctions. In the modified model, agents apply all of their time to labour and they decide on how to apportion the income from that labour between consumption and childrearing. Accordingly, equation (16) changes to:

$$
H_{t}=L_{t}\left(q_{t} h_{t}^{a}+\left(1-q_{t}\right) h_{t}^{b}\right)
$$

This modification does not qualitatively change the simulations but does dampen population perturbations, allowing for a more stable model that is less prone to extinctions of the agents.

Equation (21) becomes:

$$
z_{t}^{i}=w_{t} h_{t}^{i}=\left(\frac{A_{t} X}{L_{t}\left(q_{t} h_{t}^{a}+\left(1-q_{t}\right) h_{t}^{b}\right)}\right)^{\alpha}\left(\frac{m e_{t}^{i}+a}{e_{t}^{i}+r g_{t}+a}\right)
$$

Equations (9), (19) and (22) yield the number of children:

$$
n_{t}^{i}=\left\{\begin{array}{cc}
\frac{\gamma}{\left(\tau+\varphi^{i}\left(e_{t}\right)\right)} & \text { if } z_{t}^{i} \geq \tilde{z} \\
\frac{1-\tilde{c} / z_{t}^{i}}{\left(\tau+\varphi^{i}\left(e_{t}\right)\right)} & \text { if } \tilde{c} \leq z_{t}^{i} \leq \tilde{z} \\
0 & \text { if } z_{t}^{i} \leq \tilde{c}
\end{array}\right\} \equiv \eta\left(A_{t}, L_{t}^{a}, L_{t}^{b}, e_{t}^{a}, e_{t}^{b}, g_{t}\right)
$$

\footnotetext{
${ }^{10}$ The perturbations increase when income is between $\tilde{\mathrm{c}}$ and $\tilde{z}$. In this situation, the parent is forced to reduce the proportion of time dedicated to childrearing, which further reduces fertility.
} 
The dynamical system for the six endogenous variables is:

$$
\begin{aligned}
& A_{t+1}=\left[1+g\left(e_{t}\right)\right] A_{t} \\
& g_{t+1}=g\left(e_{t}\right) \\
& e_{t+1}^{i}=\varphi^{i}\left(e_{t}\right) ; \quad i \in a, b \\
& L_{t+1}^{i}=\eta\left(A_{t}, L_{t}^{a}, L_{t}^{b}, e_{t}^{a}, e_{t}^{b}, g_{t}\right) L_{t}^{i} ; \quad i \in a, b
\end{aligned}
$$

\section{Parameter values}

Table 1 lists the numerical values given to each parameter for the base case model. The preference parameter of the quality-preferring genotype, $\beta^{a}$, is set equal to 1 . The preference parameter of the quantity-preferring type, $\beta^{b}$, must be high enough to allow for an exit from the Malthusian state. For any value of $\beta^{b}$ below 0.842 , the economy remains in the Malthusian state because technological progress never reaches a level

\begin{tabular}{|c|c|c|c|}
\hline & & Description & Value \\
\hline \multirow{12}{*}{ Parameters } & $1-\propto$ & Labour share & 0.6 \\
\hline & $\gamma$ & Weight on children in utility function & 0.209 \\
\hline & $\tau$ & Fixed time cost of children & 0.15 \\
\hline & $\beta^{a}$ & Preference for quality of genotype $a$ & 1 \\
\hline & $\beta^{b}$ & Preference for quality of genotype $b$ & 0.85 \\
\hline & $m$ & Weighting of education in production of human capital & 2 \\
\hline & $a$ & Portion of fixed cost time of raising child towards human capital & $0.99 * \tau$ \\
\hline & $X$ & Land & 1 \\
\hline & $\tilde{c}$ & Subsistence consumption constraint & 1 \\
\hline & $k$ & Growth function parameter & 8.88 \\
\hline & d & Growth function parameter & 0.5 \\
\hline & $\mathrm{r}$ & Responsiveness of human capital to economic growth & 0.151 \\
\hline \multirow{6}{*}{$\begin{array}{l}\text { Initial } \\
\text { values }\end{array}$} & $L_{0}^{a}$ & Initial population of genotype $a$ & 0.001 \\
\hline & $L_{0}^{b}$ & Initial population of genotype $b$ & 0.665 \\
\hline & $e_{0}^{a}$ & Initial education of genotype $a$ & 0 \\
\hline & $e_{0}^{b}$ & Initial education of genotype $b$ & 0 \\
\hline & $A_{0}$ & Initial technology & 1 \\
\hline & $g_{0}$ & Initial rate of technological progress & 0 \\
\hline
\end{tabular}
high enough to induce the quantity-preferring genotype to invest in education. $\beta^{b}=0.85$ is chosen because it produces a realistic level of education in the modern growth era.

Table 1: Parameter values 
Clark (2010) provides estimates of the labour share in national income, $1-\alpha$, from the Middle Ages to modern times. The labour share increased from a low of 0.478 in the thirteenth century to above 0.6 in the early nineteenth century and to over 0.75 in the late twentieth century. We use a mid-point value of 0.6 for the labour share in income.

The severity of population perturbations in the Malthusian state and during the transition limits the range of values for the fixed time cost of children. We choose $\tau=0.15$ as at any lower value the perturbations tend to send the population extinct. ${ }^{11}$

An estimate for education expenditure, $e$, in the high-growth regime can be derived from OECD statistics. In 2009, education expenditures averaged 5.8 per cent of GDP across OECD countries (OECD 2009 Table B.2.4). The model is calibrated in a way to obtain an education level of genotype $b$ individuals of 0.059 , which is the OECD estimate for the United Kingdom. Given the predominance of genotype $b$, this is also the population average education in the modern growth regime.

The parameter $\gamma$, which is the same for both genotypes, determines the relative weight of children in the utility function. As modern fertility in developed countries is generally below replacement, $\gamma$ is set to achieve zero population growth in the high-growth era, i.e. each parent has a single child. Setting $\gamma=0.209$ and using the earlier values for $\tau$ and $e$ yields $n=\gamma /(\tau+e)=0.209 /(0.15+0.059)=1$.

Income per worker grew 2.3 per cent per year in the United Kingdom from 1950 to 2008 (Average annual growth 1960-2008 in Clark (2010), Table 33). Assuming 20 years per generation and using continuous compounding, technological progress $g$ equals 2.16 in the modern growth era. ${ }^{12}$ With this $g$ value and letting $d=0.5, k=8.88$ in equation (19).

Setting $a$ in equation (17) far below 1 or $m$ much above that required by equation (18) tends to increase population perturbations, so we set $a=0.99^{*} \tau$ and $m=2$, satisfying inequality (18) and minimising perturbations. $r=0.151$ yields the chosen equilibrium values of education and economic growth in the modern growth era.

\footnotetext{
${ }^{11}$ This value is in the range of the estimate of expenditure on children as a proportion of GDP made by Haveman and Wolfe (1995), although Haveman and Wolfe's calculation included education expenditure, which is separate from $\tau$ in the model.

${ }^{12} g^{*}=e^{\left(\frac{0.023 * 20}{\alpha}\right)}-1=e^{\left(\frac{0.023 * 20}{0.4}\right)}-1$
} 
Finally, initial values must be chosen. The initial education is zero and hence initial economic growth is zero. Initial technology, $A$, and land, $X$, are set equal to 1 . At time zero, the number of genotype $a$ and $b$ individuals is assumed to be $L_{0}^{a}=0.001$ and $L_{0}^{b}=0.665$. This is close to the equilibrium population in the first period. Using equation (21), the level of income in the first period is approximately 1.18 , which is above subsistence but such that the subsistence constraint still binds (as it is below $\tilde{z}=1 /(1-\gamma)=1.26)$.

\section{Simulation results}

The model explains the transition from Malthusian stagnation to modern economic growth, which occurred during the Industrial Revolution in the late $18^{\text {th }}$ and early $19^{\text {th }}$ centuries. Initiating the simulation shortly before the beginning of the second millennium, the take-off occurs after about 45 generations or 900 years. The length of time to the take-off depends on the initial proportion of genotype $a$ and $b$ individuals. The transition phase from Malthusian stagnation to modern growth lasts about six generations or 120 years. In that interval, the rate of technological progress surges from 1 per cent per annum to 5.7 per cent and income growth rises to the modern growth rate of 2.3 per cent per annum. Population growth increases until the time of the take-off, at which time it drops to zero during the transition phase. Figure 3 displays the behaviour of the annual growth rates of technology, income and population, and Figure 4 shows the log-levels of these variables.

Figure 3: Annual growth rate of technology, population and income

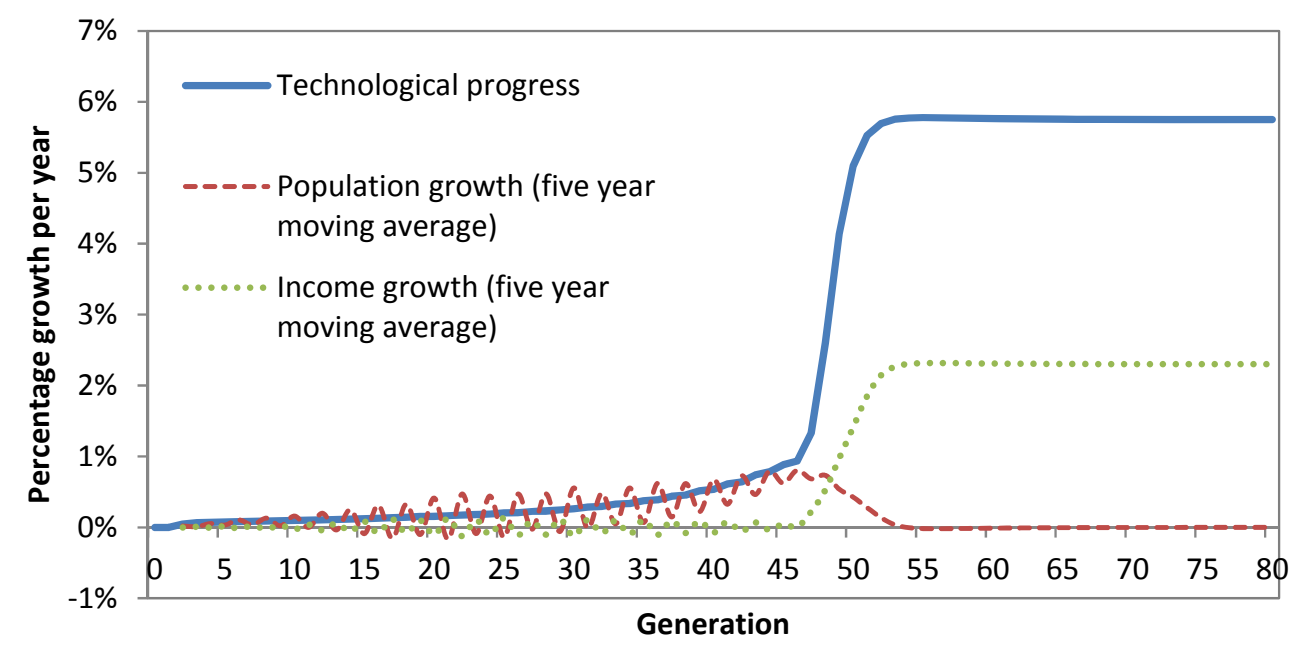


Figure 4: Level of technology, population and income

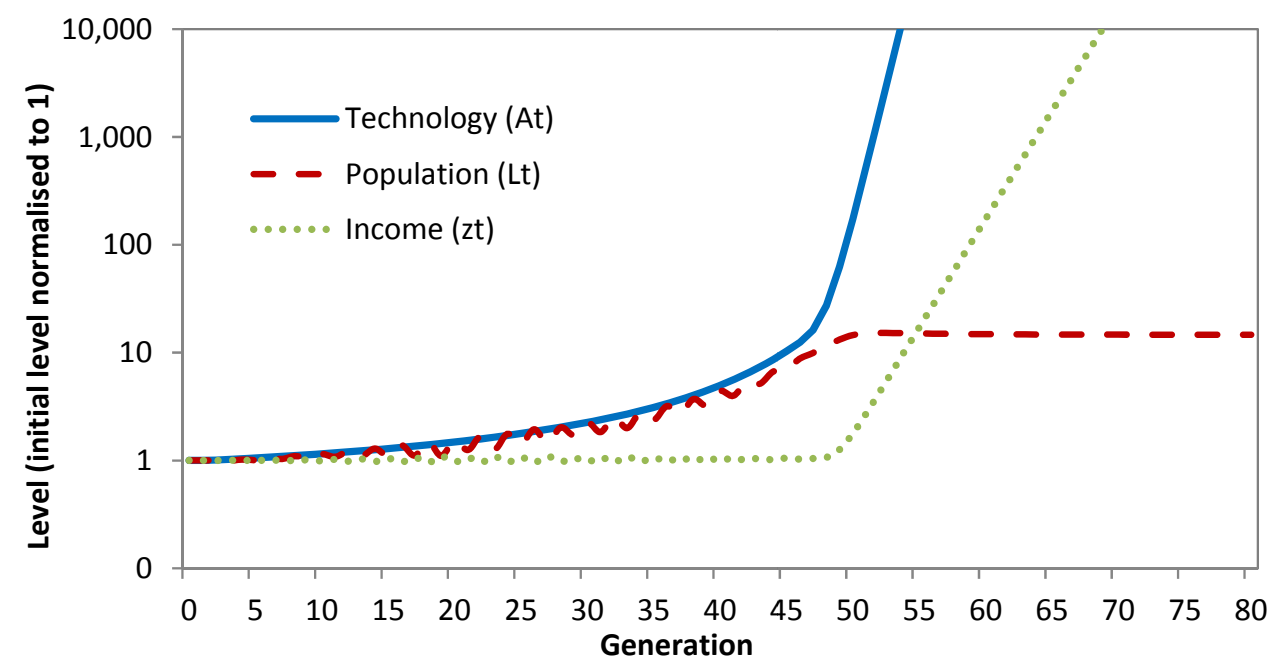

A sudden increase in the education of genotype $b$ individuals prompts the take-off in economic growth that leads out of the Malthusian state. As genotype $b$ forms the majority of the population at all times, the average level of education in the population, which determines technological progress in equation (13), is approximately that of genotype $b$. Figure 5 shows the proportion of income spent on education by each genotype.

Figure 5: Education

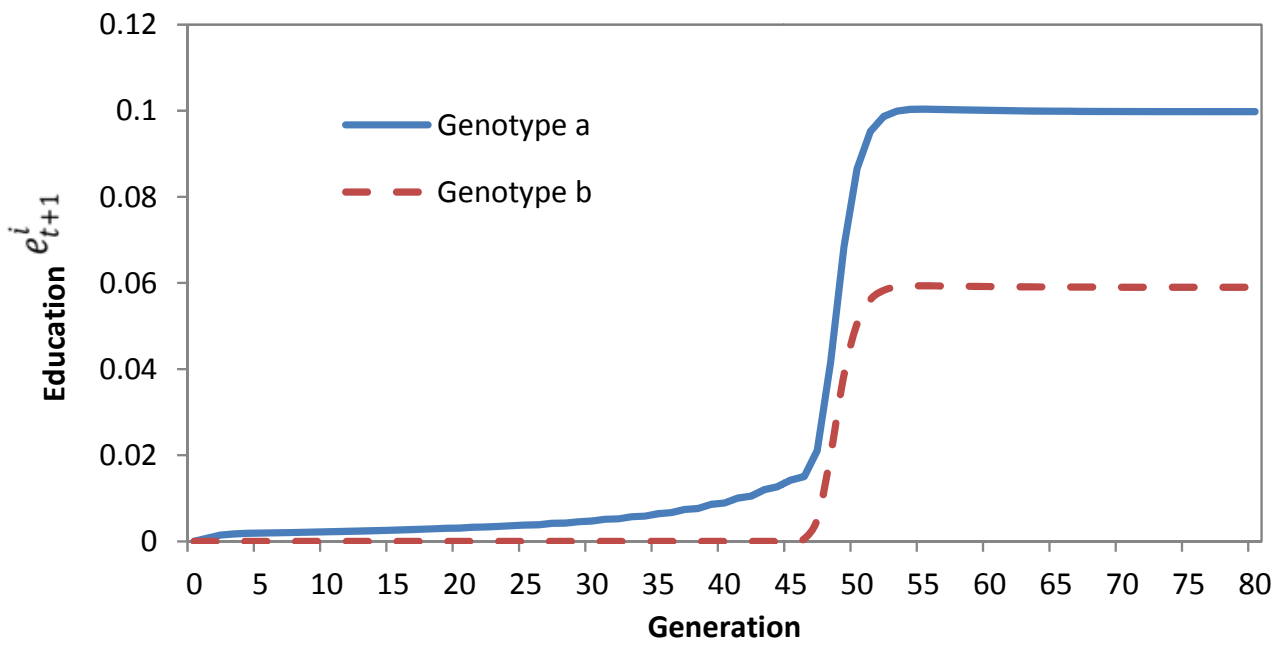

Figures 6 and 7, which relate to the fertility rate of each genotype and the genetic composition of the population, convey the fitness of the competing genotypes.

Genotype $a$ has a fitness advantage through the Malthusian era. The increase in the prevalence of genotype $a$ fosters slow technological progress until a threshold is reached that makes it worthwhile for genotype $b$ to invest in education. 
During the transition phase from Malthusian stagnation to modern growth, genotype $a$ parents begin to overinvest into education of their children to an extent that hampers their fitness. For this reason, the fitness of genotype $b$ is higher from the beginning of the transition and the prevalence of genotype $a$ starts to decrease. Genotype $a$ 's prevalence peaks at less than 5 per cent during the transition period. Thus, although the interaction between the two genotypes is crucial for the growth dynamics of the economy, a preference for quality always remains a rare trait.

Figure 6: Fertility rate (five-year moving average)

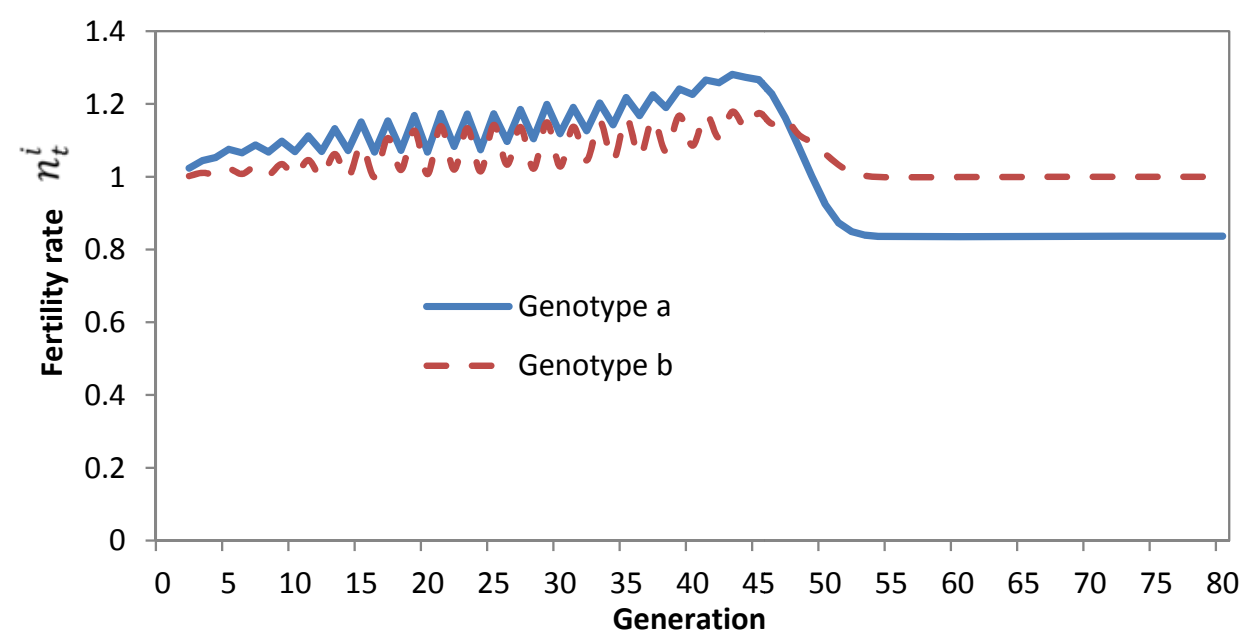

Figure 7: Proportion of population that is genotype a

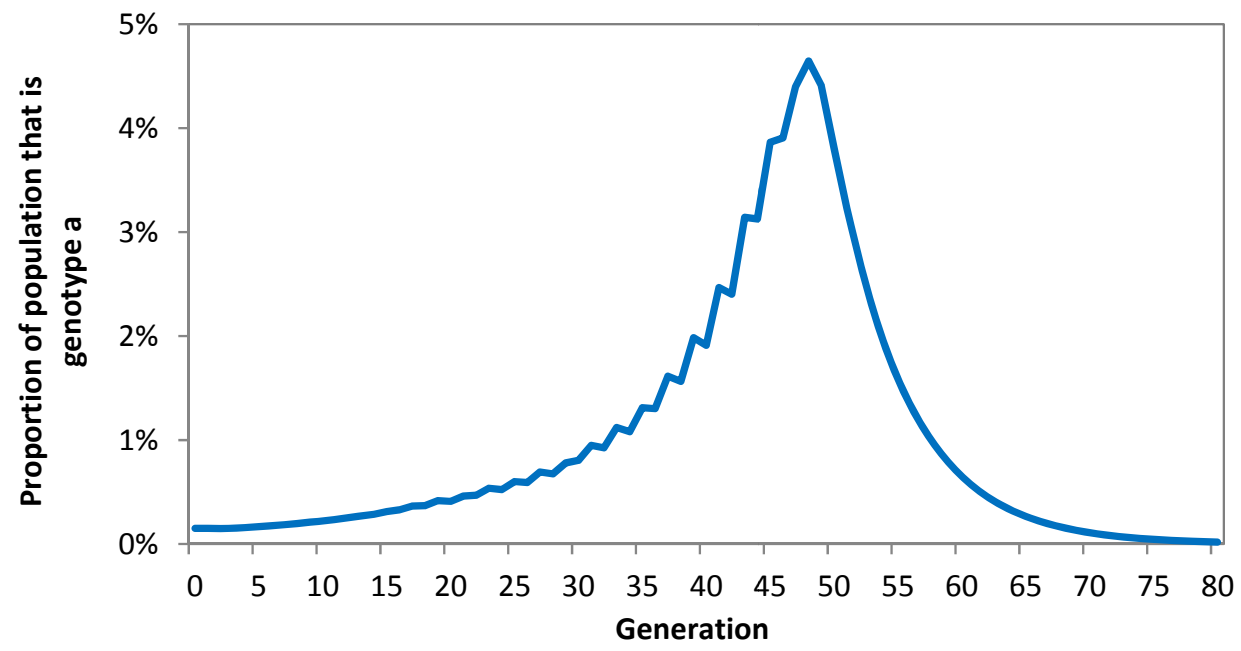

During the Malthusian era, quality-preferring parents have both more and bettereducated children, while quantity-preferring parents have fewer and less educated children. Therefore, no quantity-quality trade-off is apparent at the population level. While each individual makes a trade-off between quality and quantity, individuals that 
invest more in education also have higher fertility due to their own higher quality and income.

From the beginning of the transition out of the Malthusian state, genotype $a$ parents have better educated children, but fewer of them, while genotype $b$ parents have more children with less education. From this point, the quantity-quality trade-off can be observed at the population level.

Several studies have found evidence for the quantity-quality trade-off in the modern growth era (see Shultz (2008) for some examples). Most population level studies report a negative correlation between quantity and quality of offspring. However, as is the case of this model, whether there appears to be a trade-off at the population level is not determinative of whether an individual faces that trade-off. To assess whether there is an individual trade-off, a number of studies have examined the effect of exogenous events such as twins or the sex composition of births. As is noted by Schultz, these exogenous shocks to quantity tend to have a smaller effect on child quality at the individual level than is observed at the population level, suggesting that some of the quantity-quality relationship observed at the population level may not be a direct quantity-quality trade-off but rather a reflection of other relationships.

Only a few studies on the quantity-quality trade-off utilise data around the time of or before the Industrial Revolution. Becker et al. (2010) found a quantity-quality trade-off analysing population data from 334 Prussian counties in 1849. Becker et al. suggest that the early date of these findings is consistent with the Galor and Moav model in which the quantity-quality trade-off is present before the period of modern economic growth. This may not be the case, however, as in the Galor and Moav model there is no quantity-quality trade-off apparent at the population level during the Malthusian state.

One source of pre-industrial data is from wills in England, as detailed in Clark and Hamilton (2006), Clark (2007) and Clark and Cummins (2009a, 2009b). From an examination of English wills dated 1585 to 1638, Clark and Hamilton found that wealth was strongly (and positively) predictive of reproductive success. The positive association between income and fertility in the Malthusian state is consistent with the Galor and Moav model.

A paper by Clark and Cummins (2009a) presents some evidence on the trade-off at the individual level. While preliminary results, Clark and Cummins found that before 1780 
there was a significant (but modest) negative relationship between family size and the wealth of sons. ${ }^{13}$ This suggests that a quantity-quality trade-off had been present before the Industrial Revolution. For the period 1780 to 1890 , there was also a negative trade-off, although it may be of a smaller (or even negligible magnitude).

Clark and Cummins note that this result potentially requires a revision of the theoretical basis of the Galor and Moav model. As the Galor and Moav model economy transitions out of the Malthusian state, the trade-off between quantity and quality increases, with the higher level of technological progress in the modern growth state increasing the returns (in the form of human capital) to education. The absence of an increasing trade-off in the empirical data may suggest that other factors are relevant, such as a direct genetic transfer of quality between generations. ${ }^{14}$

Another empirical issue with the Galor and Moav model is the population dynamics. The decline in the fertility of the quality-preferring genotype during the transition out of the Malthusian state is consistent with the early decline in fertility among the wealthy, which Clark and Cummins (2009b, 2010) documented. However, the Galor and Moav model predicts that the population will stabilise during the transition phase, which is too early. High rates of population growth persisted in Great Britain and other industrial countries to the end of the $19^{\text {th }}$ century. This presents an issue for the Galor and Moav model and other models that incorporate a quantity-quality trade-off. If an increase in child quality is expected to drive the transition to a modern growth state, a contemporaneous change in quantity might be expected due to the presence of the trade-off. ${ }^{15}$

\footnotetext{
${ }^{13}$ Clark and Cummins are assembling a larger data set that will improve the robustness of the results and allow for additional controls to be included such as birth order and gender composition of siblings.

${ }^{14}$ Clark (2005) also suggested that there was no evidence of a market premium for skills that would provide a signal to parents to invest in the human capital of their children.

${ }^{15}$ Clark and Cummins (2009a) tested the hypothesis that changes in child mortality were responsible for the delayed demographic transition. They found that this hypothesis was not supported by the data.
} 


\section{Population perturbations in the Malthusian state}

The simulation of the Galor and Moav model produces population cycles during the Malthusian state. Considering the Galor and Weil model, Lagerlof (2006) explained the endogenous cycles as follows:

\footnotetext{
"When population in the current period is large, land per agent is low, and per capita income close to subsistence. Thus fertility is close to zero and population in the next period pushed almost to extinction. This makes next period's per capita incomes high, spurring a phase of population growth until overpopulation sets in and the cycle starts all over again.”
}

We can make some further observations about these population cycles. First, the cycles are irregular perturbations that do not settle into a clear pattern. Second, they are highly dependent on the initial conditions. As shown by May (1976), a first-order difference equation can produce a large array of behaviours from stable points to apparently random cycles within a single functional form. In this section, it is shown that population growth in the Malthusian era is defined by a first order difference equation and that the pre-industrial population cycles hinge on the fixed time cost of childrearing.

In the early Malthusian state, the quantity-preferring genotype $b$ dominates the population. Genotype $b$ adults do not educate their children, resulting in a population of:

$$
L_{t+1}=\left\{\begin{array}{cc}
\frac{\gamma}{\tau} L_{t} & \text { if } z_{t}^{b} \geq \tilde{z} \\
\left(\frac{1-\tilde{c} / z_{t}^{i}}{\tau}\right) L_{t} & \text { if } \tilde{c} \leq z_{t}^{b} \leq \tilde{z} \\
0 & \text { if } z_{t}^{b} \leq \tilde{c}
\end{array}\right.
$$

If $\tilde{c} \leq z_{t}^{b} \leq \tilde{z}$, as would be the case during the Malthusian era, and setting $\tilde{c}, A_{t}$, and $\mathrm{X}$ equal to 1 , the population equation simplifies to:

$$
L_{t+1}=\frac{1}{\tau} L_{t}\left(1-L_{t}^{\alpha}\right)
$$

Setting $L^{*}=L_{\mathrm{t}}=L_{\mathrm{t}+1}$, the equilibrium for the population is $L^{*}=(1-\tau)^{1 / \alpha}$. The equilibrium is unstable if $\partial L_{t+1} / \partial L_{t}>|1|$. Taking the derivative of equation (26) yields:

$$
\frac{\partial L_{t+1}}{\partial L_{t}}=\frac{1}{\tau}-\frac{1+\alpha}{\tau}(1-\tau)
$$


Equation (27) shows that the stability of the population equilibrium depends on the value of the fixed time cost of childrearing, $\tau$. For $\alpha=0.6$, the equilibrium is unstable if $\tau \leq 0.2307 .{ }^{16}$ Figure 8 presents a bifurcation plot of equation (26) showing the population after 100 generations, $L_{100}$. Iterations of equation (26) are performed for values of $\tau$ between 0.15 and 0.3 at intervals of 0.001 . At each step, equation (26) is iterated 100 times, starting with random values for $L_{0}$ between 0 and 1 .

Figure 8: Bifurcation plot of equation (26)

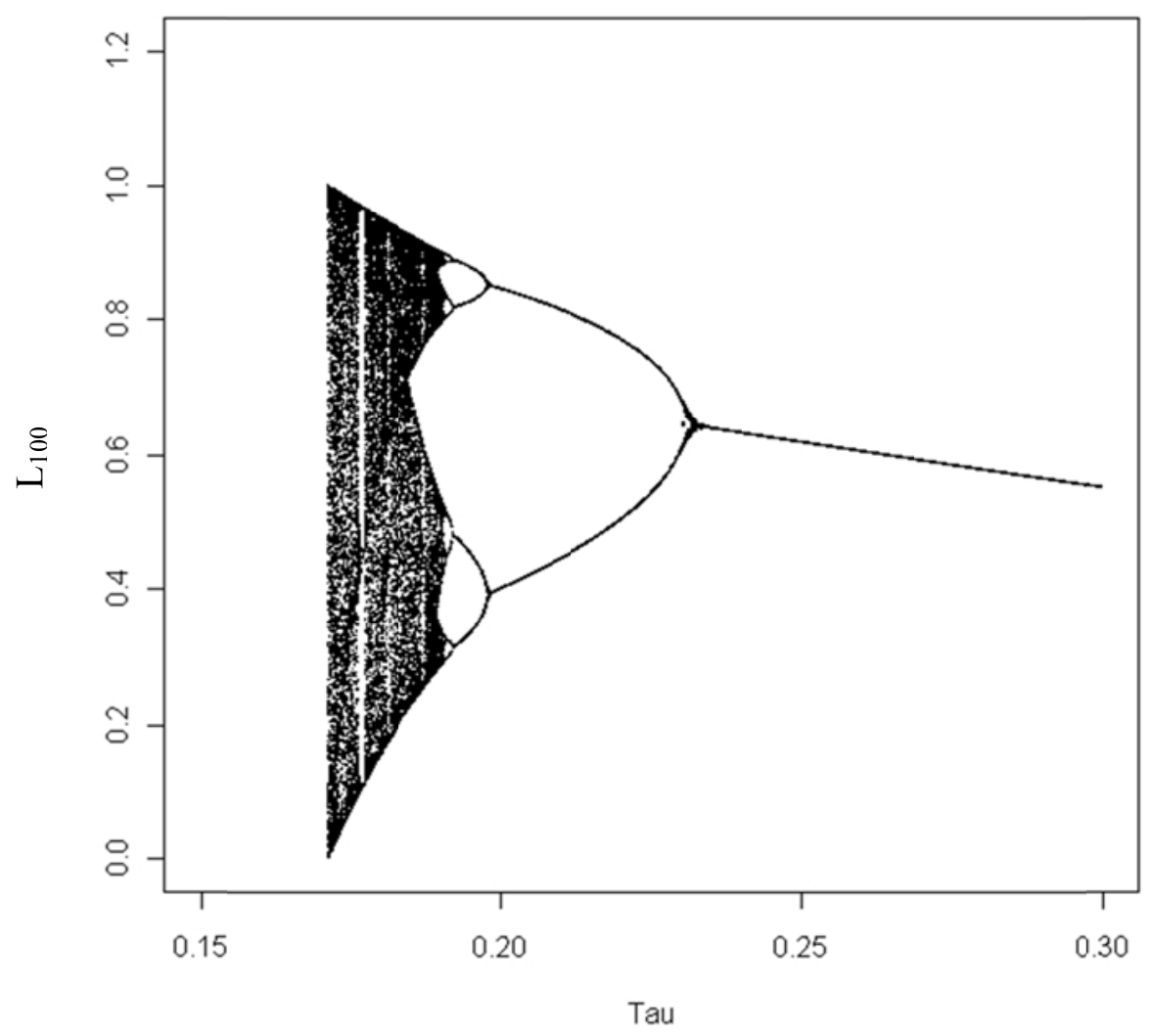

For any value of $\tau$ below 0.17 , the population has collapsed into extinction after 100 generations. For values of $\tau$ between approximately 0.17 and 0.19 , the behaviour of the population is chaotic. Above 0.19, the population oscillates between two or more values, while above 0.2307 , it settles to a stable equilibrium. This explains Lagerlof's (2006) observation that there are no population perturbations if the fixed time cost of children is sufficiently high.

\footnotetext{
${ }^{16}$ The equilibrium of equation (26) is also unstable if $\tau>1$. However, $\tau>1$ is not feasible as a parent cannot use more than the entire time endowment to raise a child.
} 
If less than 100 iterations are performed, the population may survive for some starting values below 0.17 , suggesting that the population may not become extinct if the take-off out of Malthusian state occurs early enough. In the models explored in this paper, the slight technological progress due to the presence of genotype $a$ also increases the probability of survival for some starting values.

\section{Model extension - mutation and migration}

Galor and Moav did not use their model to consider the possibility of the evolution of new genotypes with different preferences over quality and quantity of children. As there is no mutation or migration, the genetic makeup of the population alters only because the prevalence of each genotype changes over time. While this is immaterial for the short transition phase out of the Malthusian state, it is relevant for the Malthusian era before the emergence of modern economic growth and it matters for the stability of the modern growth era. In this section, we show that the number of genotypes affects the predictions of the Galor and Moav model. The main finding is that a growing economy may regress to Malthusian conditions if a third genotype emerges that values education less than the other two.

Using the same utility function as before, the quantity-quality preference parameters for the three genotypes are: $\beta^{a}=1.0, \beta^{b}=0.85$ and $\beta^{c}=0.7$. All other parameters of the model are the same as in Table 1, except the initial levels of the subpopulations, which are $\boldsymbol{L}_{\mathbf{0}}^{\boldsymbol{a}}=\mathbf{0 . 0 0 1}, \boldsymbol{L}_{\mathbf{0}}^{\boldsymbol{b}}=\mathbf{0 . 6 6 4}$ and $\boldsymbol{L}_{\mathbf{0}}^{\boldsymbol{c}}=\mathbf{0 . 0 0 1}$. Thus, both the quality-preferring genotype $a$ and the new strongly quantity-preferring genotype $c$ are minute minorities at the beginning of the simulation, which may have emerged through mutation or migration.

Figure 9 shows that the first 60 generations of the simulation are similar to the baseline simulation in Section 8. The transition out of the Malthusian state occurs quite quickly within six generations after the $45^{\text {th }}$ generation. Population growth again peaks early during the transition phase and the population stabilizes. Then, a growth era with high technological progress and income growth begins. However, in the model with three genotypes, the growth era lasts for only about 20 generations, or 400 years. Economic growth abates because there is a renewed increase in population after about generation 75 , which does not occur in the model with two genotypes. By generation 105, 
technological progress has ended and income growth is negative. The fall in per capita income continues until it has returned to the initial Malthusian level by about generation 260. Since technological progress is permanent, the economy supports a much higher population during the second Malthusian era. Figure 9 displays the growth rates of technology, population and income, and Figure 10 shows the level of these variables.

Figure 9: Annual growth rate of technology, population and income

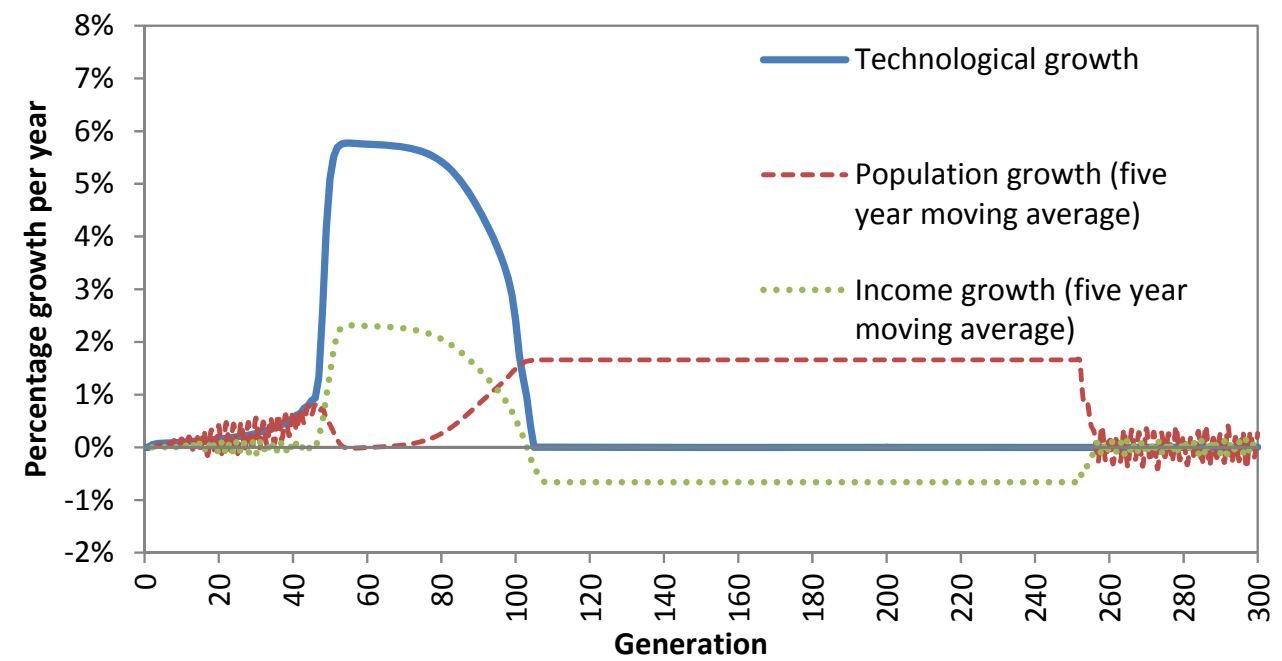

Figure 10: Level of technology, population and income

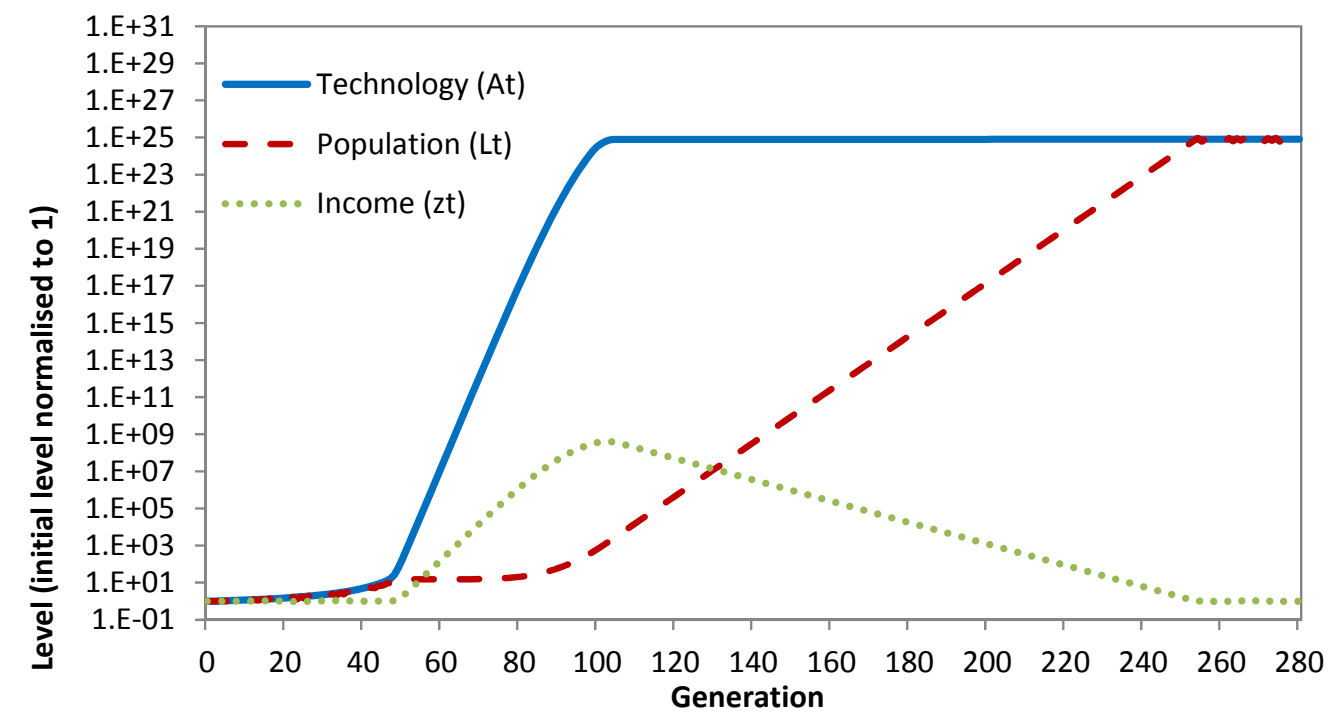

Figures 11, 12 and 13 reveal the behaviour of education, fertility and the genetic makeup of the population. In the initial Malthusian state, genotype $a$ has the highest fitness as education increases potential income, and genotypes $b$ and $c$ have equal fitness as neither invests in education. Once the high growth era commences, natural 
selection favours genotype $c$ because the other two genotypes overeducate their children. The return to the Malthusian state is caused by a decline in per capita human capital, which is driven by the higher fertility of genotype $c$ and its increasing prevalence in the population. Since genotype $c$ does not invest in education, the average education level of the population declines and technological progress stalls. After the return to Malthusian conditions, the bulk of the population is genotype $c$, with a small proportion of genotype $b$ and genotype $a$ almost driven to extinction.

Figure 11: Education

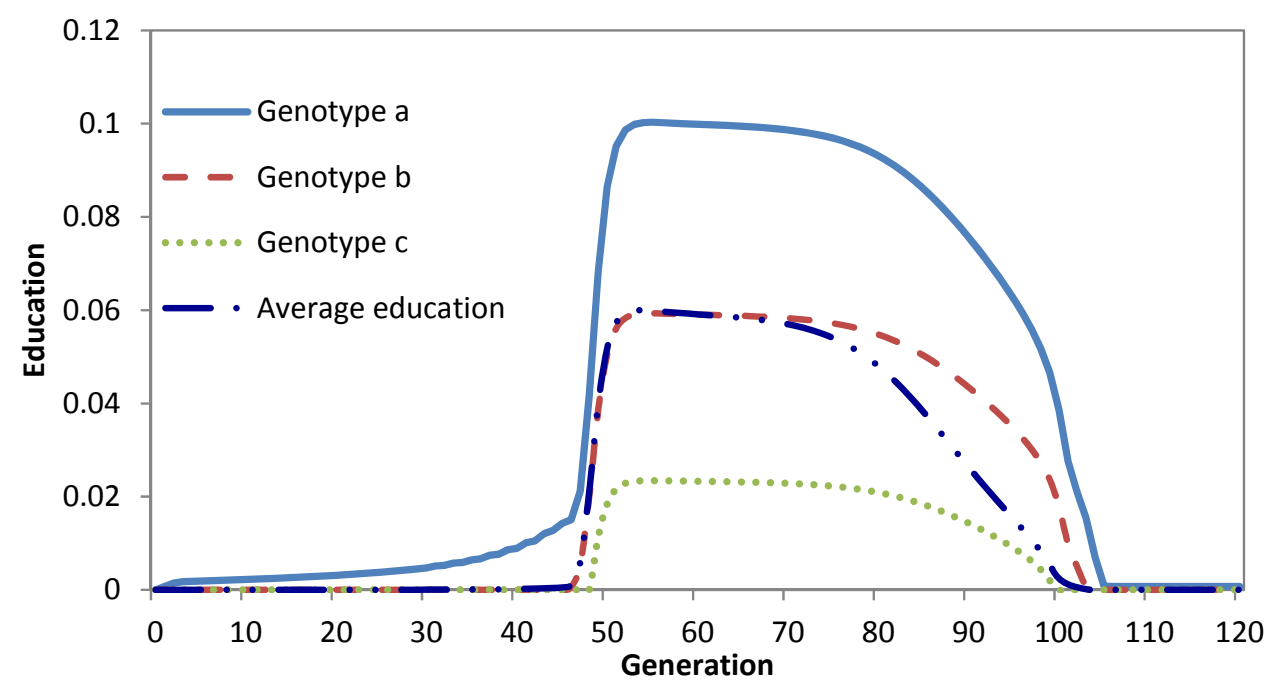

Figure 12: Fertility rate (five-year moving average)

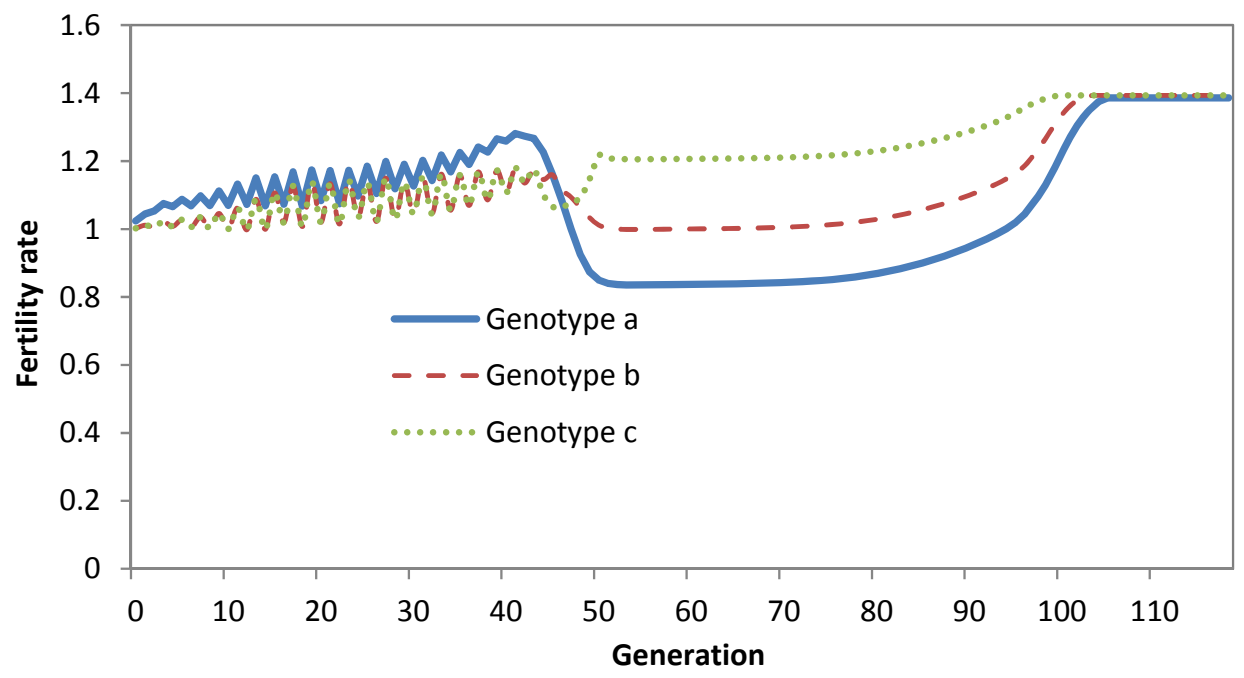


Figure 13: Proportion of population of each genotype

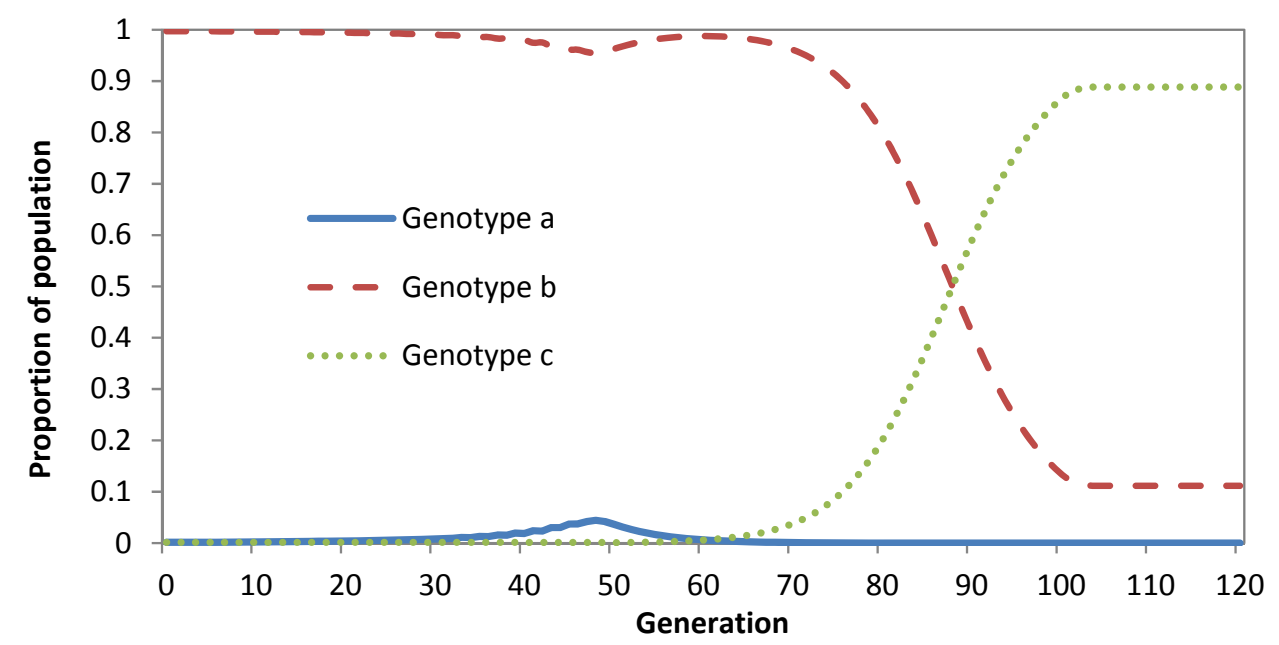

Figures 14, 15 and 16 display the dynamics of the economy after the return to Malthusian conditions. At first, genotype $a$ regains the fitness advantage and again starts to increase in proportion of the population. It takes several hundred generations for genotype $a$ to recover to meaningful numbers from their near extinction at the beginning of the second Malthusian state. The renewed increase in the prevalence of genotype $a$ again promotes technological progress, but it is not sufficient for another exit from Malthusian stagnation. The second Malthusian state is permanent because technological progress is matched by population growth. Thus, the situation is different from the initial Malthusian state where a small number of genotype $c$ individuals emerged through mutation or migration. In the second Malthusian state, there is a high proportion of genotype $c$ whose fertility absorbs any increase in income. After generation 675, a growth cycle repeats itself about every 25 years without ever leading out of Malthusian stagnation. The cycles are generated by the interaction between genotype $a$, which drives technological progress, and genotype $c$, whose high fertility dilutes the average level of income in the population. 
Figure 14: Proportion of population of each genotype

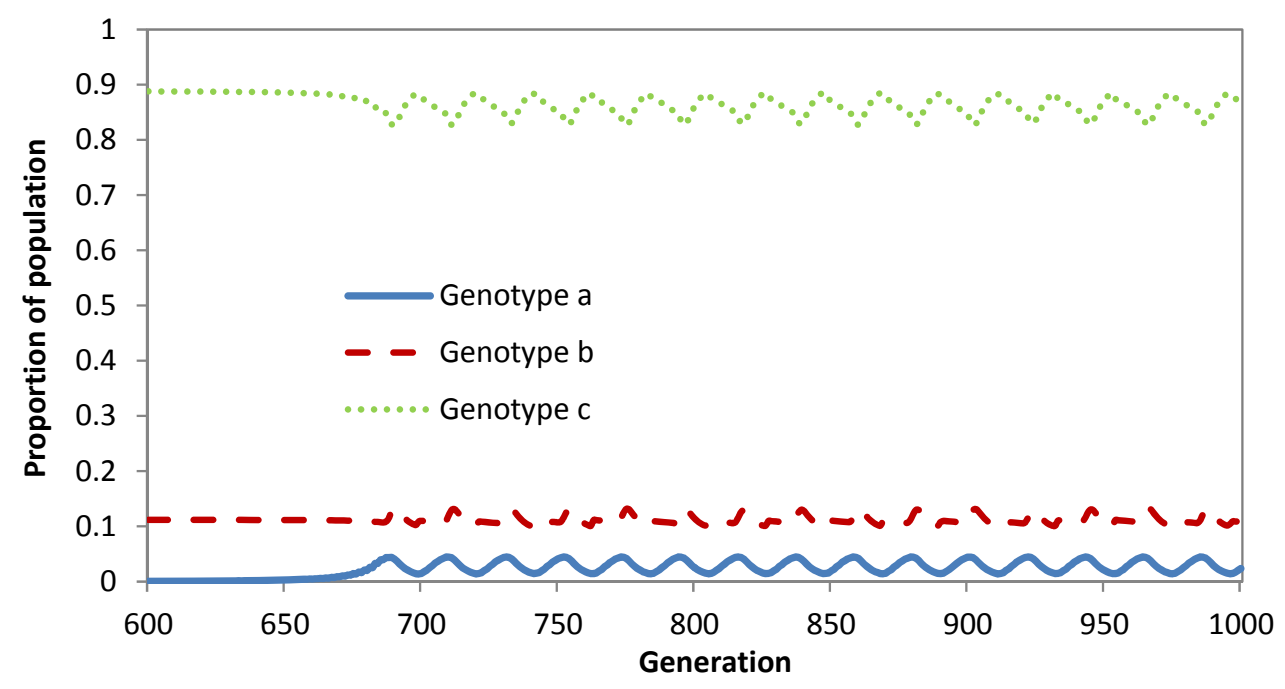

Figure 15: Education

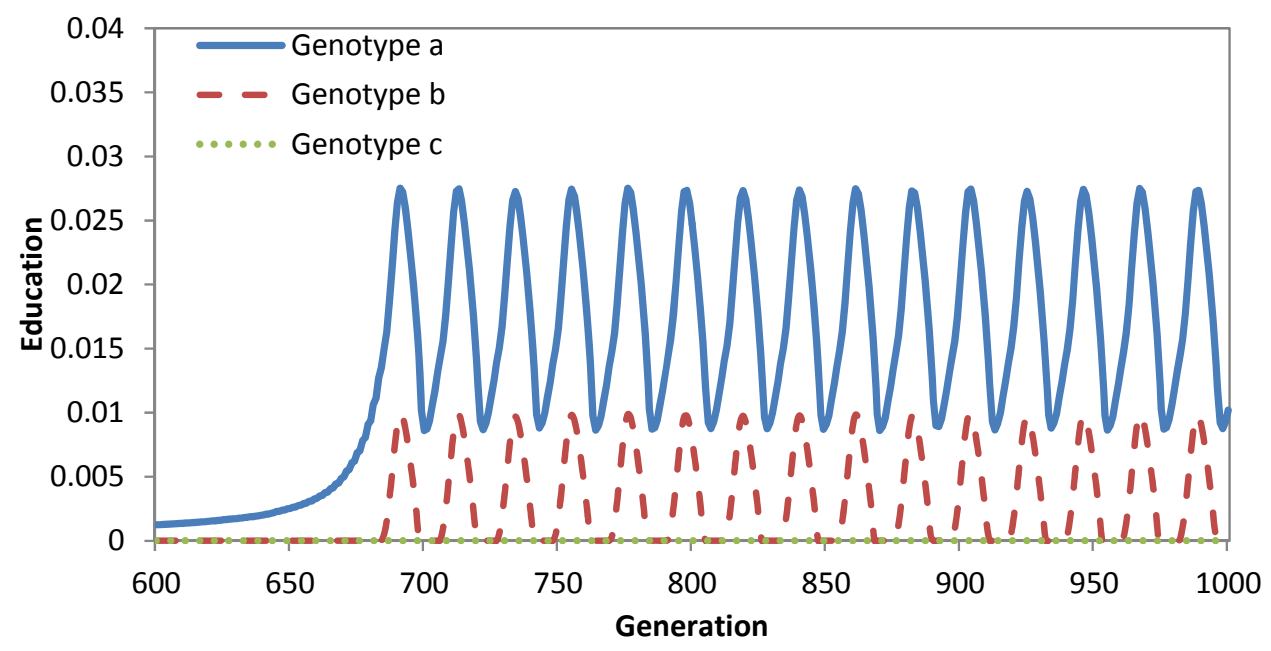


Figure 16: Level of technology, population and income

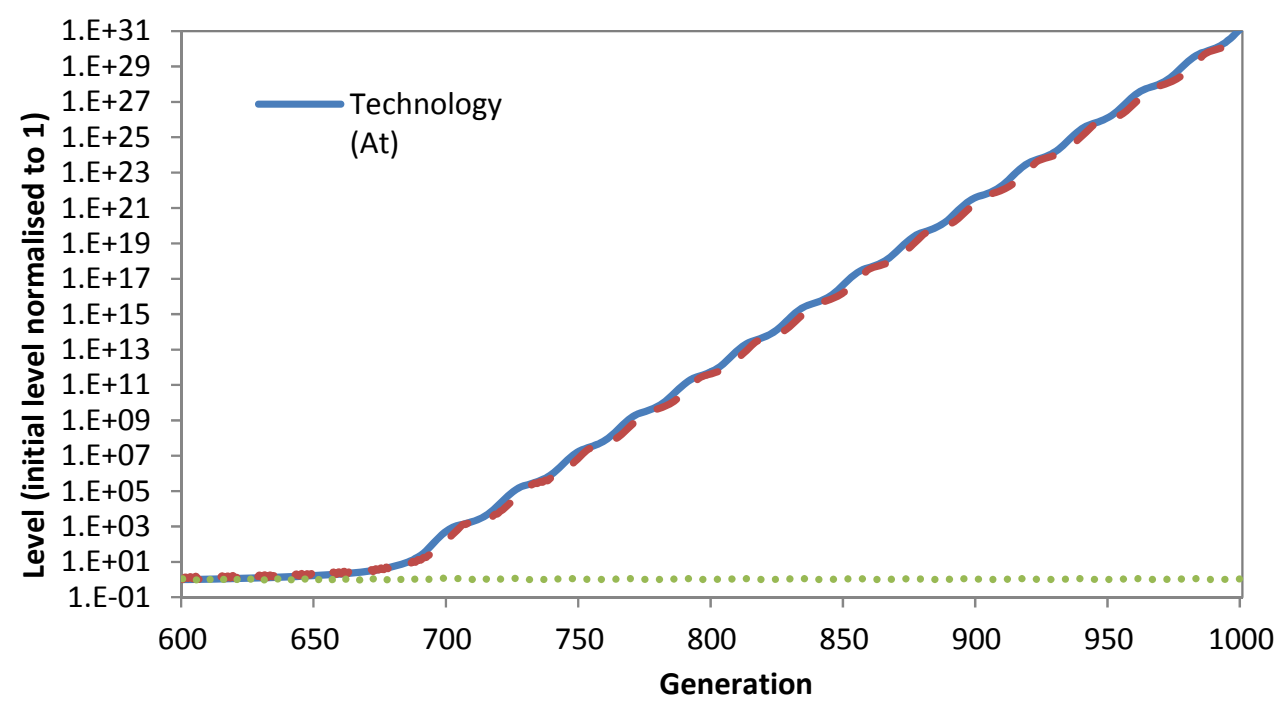

The simulation of the extended Galor and Moav model that is presented in this section is compatible with a number of scenarios. It is indicative of a case where a third genotype $c$ emerges through mutation or migration in a situation with two genotypes during the Malthusian era, or alternatively, after the exit of the initial Malthusian era. In each case, the simulation begins with a small minority of genotype $a$ and $c$ individuals. Eventually, the genotype $c$ individuals will dominate the population and drive the economy back into Malthusian conditions.

\section{Conclusion}

The simulation of the Galor and Moav model results in a pattern of income and population growth that resembles the period of Malthusian stagnation and the take-off into a modern growth era. However, the timing of the demographic transition concurrent with the commencement of income growth is not consistent with empirical evidence that the demographic transition occurred several generations after the initial take-off. This highlights issues with the quantity-quality trade-off mechanism that underlies the model and suggests that alternative or additional factors should be considered.

The simulation has also demonstrated that the model is heavily dependent on the selection of parameters, with minor variations in preference for quality or the resource cost per child substantially modifying the model outcomes. One area of fragility is the cyclical behaviour in the Malthusian era, which Lagerlof (2006) also observed in his 
simulation of the Galor and Weil (2000) model. The present paper identifies the first order difference equation that determines the population dynamics as the cause of the oscillations and describes how the time cost of children variable influences their nature.

The instability of the model also extends to the biological features. If the model includes more than the two genotypes with fixed preferences between quantity and quality, the modern growth state is not stable and is susceptible to invasion by a strongly quantitypreferring genotype. This can return the population to the Malthusian state and in the case of the scenario examined, the final Malthusian state is permanent.

The simulation exercise highlights a number of possible further considerations relevant to a biological evolution theory of the Industrial Revolution. Consideration could be given to the individuals having a higher degree of phenotypic plasticity, in that they have some flexibility in their response to technological progress. This could allow quality-preferring types to reduce their response to technological progress where it is clear that fertility was being substantially hampered by their over-investment in education. Phenotypic plasticity could add some robustness to the modern-growth state by allowing quality-preferring types to maintain a share of the total population. However, in the Galor and Moav model as presented above, a genotype that does not invest in education when income is above subsistence will always have a fitness advantage and drive the model back towards the Malthusian state.

Furthermore, the introduction of stochastic mutation or migration would enable examination of a richer biological environment. This may require the use of an agent-based model. The introduction of an agent-based model (possibly incorporating overlapping generations) may also allow moderation of the perturbations in the Malthusian state without requiring the use of implausible or arbitrary parameters. 


\section{References}

Ashraf, Q. \& Galor, O., 2010. The "Out of Africa" Hypothesis, Human Genetic Diversity, and Comparative Economic Development. Available at: http://www.brown.edu/Departments/Economics/Papers/2010/2010-7_paper.pdf.

Becker, G.S., 1976. Altruism, Egoism and Genetic Fitness: Economics and Sociobiology. Journal of Economic Literature, 14, pp.817-826.

Becker, G.S., 1960. An Economic Analysis of Fertility. In Universities National Bureau, eds. Demographic and Economic Change in Developed Countries. Princeton: UMI, pp. 225-256. Available at: http://www.nber.org/books/univ60-2 [Accessed December 5, 2010].

Becker, G.S. \& Lewis, H.G., 1974. Interaction between Quantity and Quality of Children. In T. W. Schultz, ed. Economics of the Family: Marriage, Children, and Human Capital. UMI, pp. 81-90. Available at: http://www.nber.org/books/schu74-1 [Accessed December 5, 2010].

Becker, G.S., Murphy, K.M. \& Tamura, R., 1990. Human Capital, Fertility and Economic Growth. Journal of Political Economy, 98(5), p.S12-S37.

Becker, S.O., Cinnirella, F. \& Woessmann, L., 2010. The trade-off between fertility and education: evidence from before the demographic transition. Journal of Economic Growth, 15(3), pp.177-204.

Cavalli-Sforza, L.L., Menozzi, P. \& Piazza, A., 1994. The History and Geography of Human Genes, Princeton: Princeton University Press.

Clark, G., 2007. A Farewell to Alms: A Brief Economic History of the World, Princeton and Oxford: Princeton University Press.

Clark, G., 2005. The Condition of the Working Class in England, 1209-2004. Journal of Political Economy, 113(6), pp.1307-1340.

Clark, G., 2010. The macroeconomic aggregates for England, 1209-2008. In Research in Economic History. Research in Economic History. Bingley: Emerald Group Publishing, pp. 51-140.

Clark, G. \& Cummins, N., 2010. Malthus to Modernity: England's First Fertility Transition, 1760-1800. Available at: http://www.econ.ucdavis.edu/faculty/gclark/papers/Demographic\%20Transition \%202010.pdf [Accessed December 18, 2010].

Clark, G. \& Cummins, N., 2009a. The Origins of Modern Growth: Fertility and Human Capital in England, 1500-1914. In University Seminar in Economic History. Columbia University. Available at: http://www.econ.barnard.columbia.edu/ econhist/papers/Clark_Cummins_Nov2 009.pdf.

Clark, G. \& Cummins, N., 2009b. Urbanization, Mortality, and Fertility in Malthusian England. American Economic Review: Papers and Proceedings, 99(2), pp.242247. 
Clark, G. \& Hamilton, G., 2006. Survival of the Richest: The Malthusian Mechanism in Pre-Industrial England. Journal of Economic History, 66(3), pp.707-736.

Darwin, C., 1859. On the Origin of Species by Means of Natural Selection, London: John Murray, Albemarle Street.

Galor, O. \& Michalopoulos, S., 2011. Evolution and the Growth Process: Natural Selection of Entrepreneurial Traits. Journal of Economic Theory, forthcoming. Available at: http://ideas.repec.org/p/bro/econwp/2011-9.html.

Galor, O. \& Moav, O., 2002. Natural Selection and the Origin of Economic Growth. Quarterly Journal of Economics, 117(4), pp.1133-1191.

Galor, O. \& Weil, D.N., 2000. Population, Technology, and Growth: From Malthusian Stagnation to the Demographic Transition and Beyond. American Economic Review, 90(4), pp.806-828.

Graves, J.L., 2002. What a tangled web he weaves. Anthropological Theory, 2(2), pp.131 -154.

Hansson, I. \& Stuart, C., 1990. Malthusian Selection of Preferences. American Economic Review, 80(3), pp.529-544.

Haveman, R. \& Wolfe, B., 1995. The Determinants of Children's Attainments: A Review of Methods and Findings. Journal of Economic Literature, 33(4), pp.1829-1878.

Hirshleifer, J., 1977. Economics from a Biological Viewpoint. Journal of Law and Economics, 20(1), pp.1-52.

Lagerlöf, N.-P., 2006. The Galor-Weil model revisited: A quantitative exercise. Review of Economic Dynamics, 9(1), pp.116-142.

May, R.M., 1976. Simple mathematical models with very complicated dynamics. Nature, 261, p.459.

Nelson, R.R. \& Winter, S.G., 1982. An Evolutionary Theory of Economic Change, Cambridge, Mass: Harvard University Press.

Netzer, N., 2009. Evolution of Time Preferences and Attitudes toward Risk. American Economic Review, 99(3), pp.937-955.

OECD, 2009. Education at a Glance 2009: OECD Indicators, OECD Publishing. Available at: http://www.oecd.org/document/24/0,3343,en_2649_39263238_43586328_1_1_ 1_1,00.html\#5.

R Development Core Team, 2010. R: A Language and Environment for Statistical Computing, Vienna, Austria: R Foundation for Statistical Computing. Available at: http://www.r-project.org.

Robson, A.J. \& Samuelson, L., 2007. The Evolution of Intertemporal Preferences. American Economic Review, 97(2), pp.496-500. 
Robson, A.J. \& Szentes, B., 2008. Evolution of Time Preference by Natural Selection: Comment. American Economic Review, 98(3), pp.1178-1188.

Rogers, A.R., 1994. Evolution of Time Preference by Natural Selection. American Economic Review, 83(3), pp.460-481.

Rubin, P.H. \& Paul II, C.W., 1979. An Evolutionary Model of Taste for Risk. Economic Inquiry, 17(4), pp.585-596.

Schultz, T.P., 2008. Population Policies, Fertility, Women's Human Capital, and Child Quality. In T. P. Schultz \& J. Strauss, eds. Hanbook of Development Economics. Handbooks in Economics. Amsterdam: Elsevier B.V., p. 3249.

Spolaore, E. \& Wacziarg, R., 2009. The Diffusion of Development. Quarterly Journal of Economics, 124(2), pp.469-529. 


\section{Appendix A: R code for simulations}

The simulations in this paper were conducted using R ( $R$ Development Core Team 2010), a free language and environment for statistical computing. The software is available from http://www.r-project.org

\section{Base case simulation}

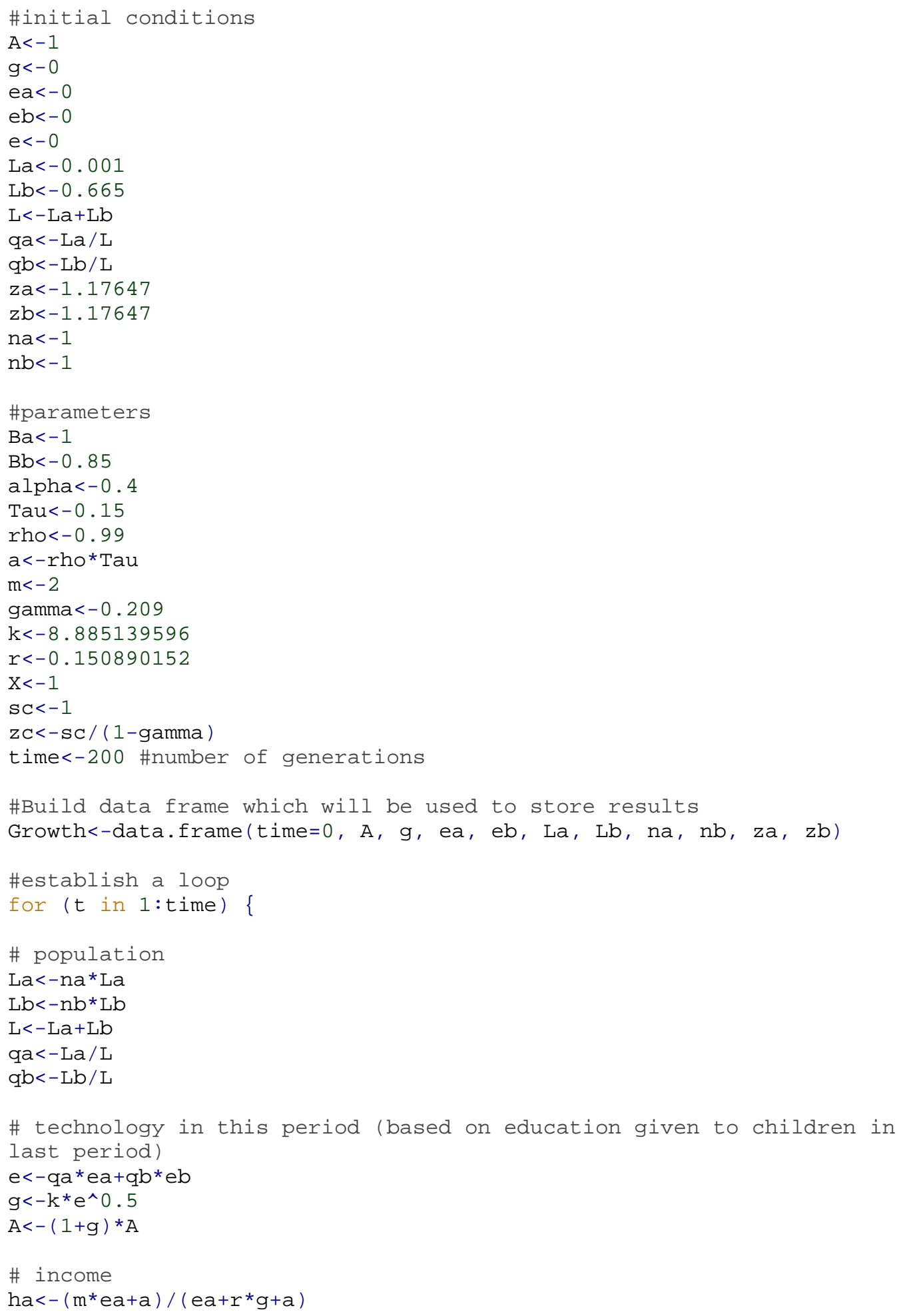




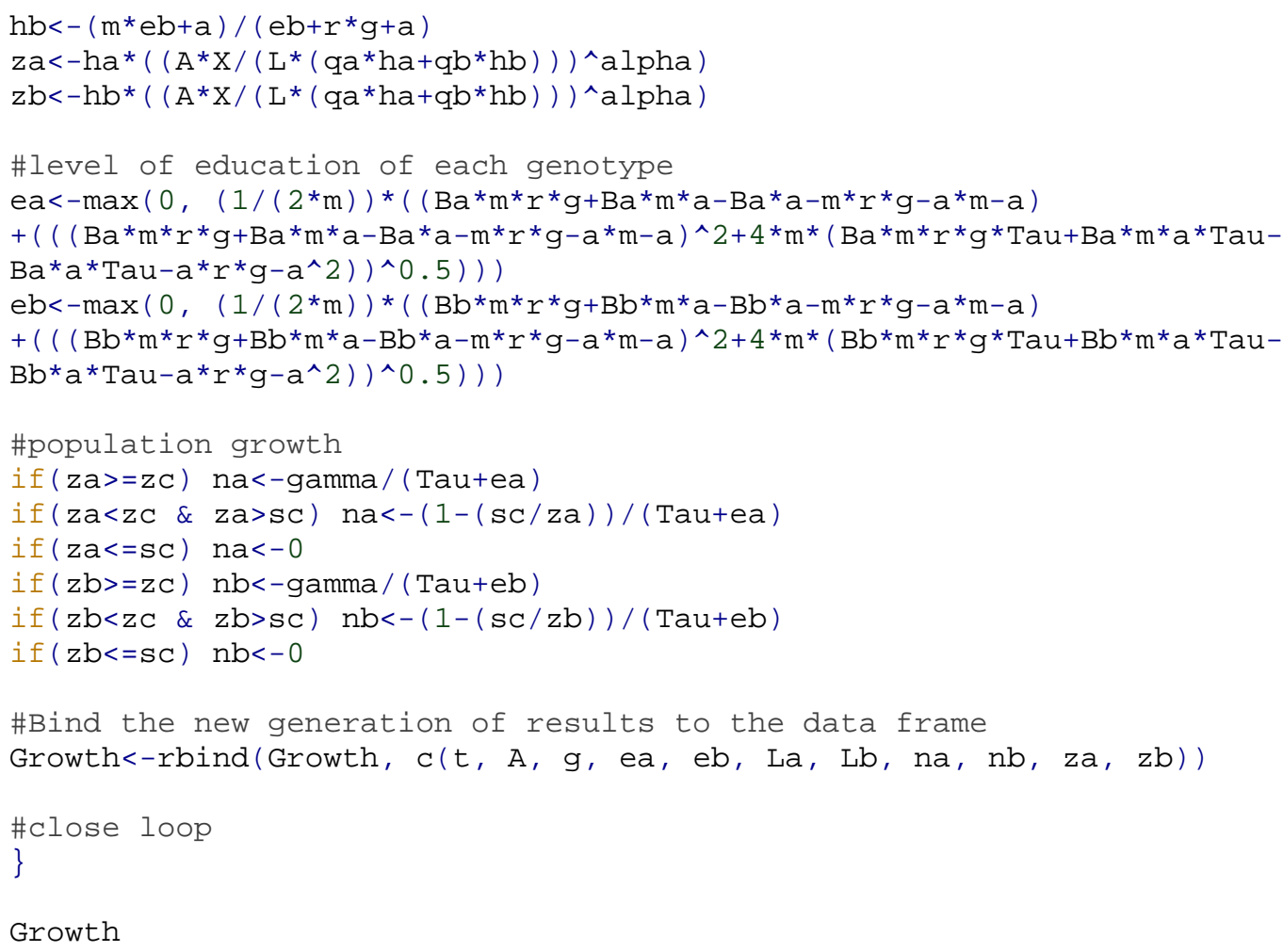

Growth

\section{Simulation with three genotypes}

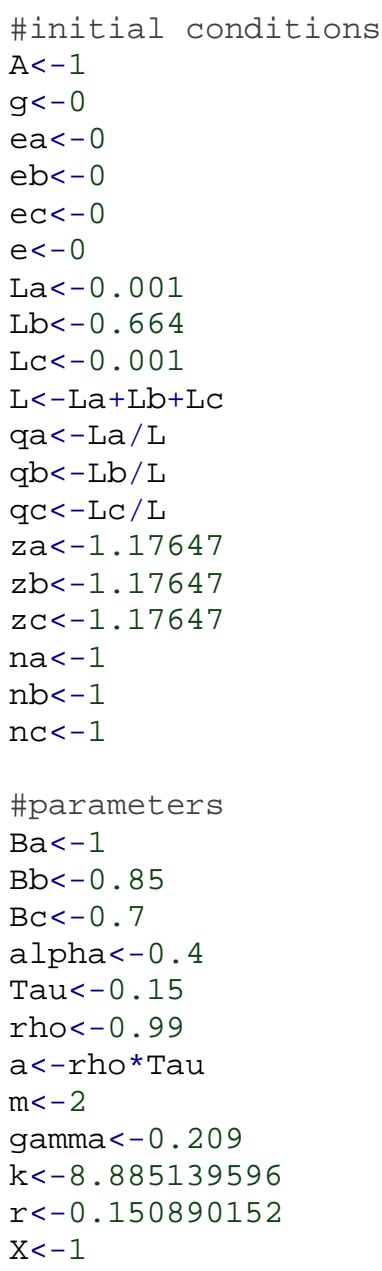




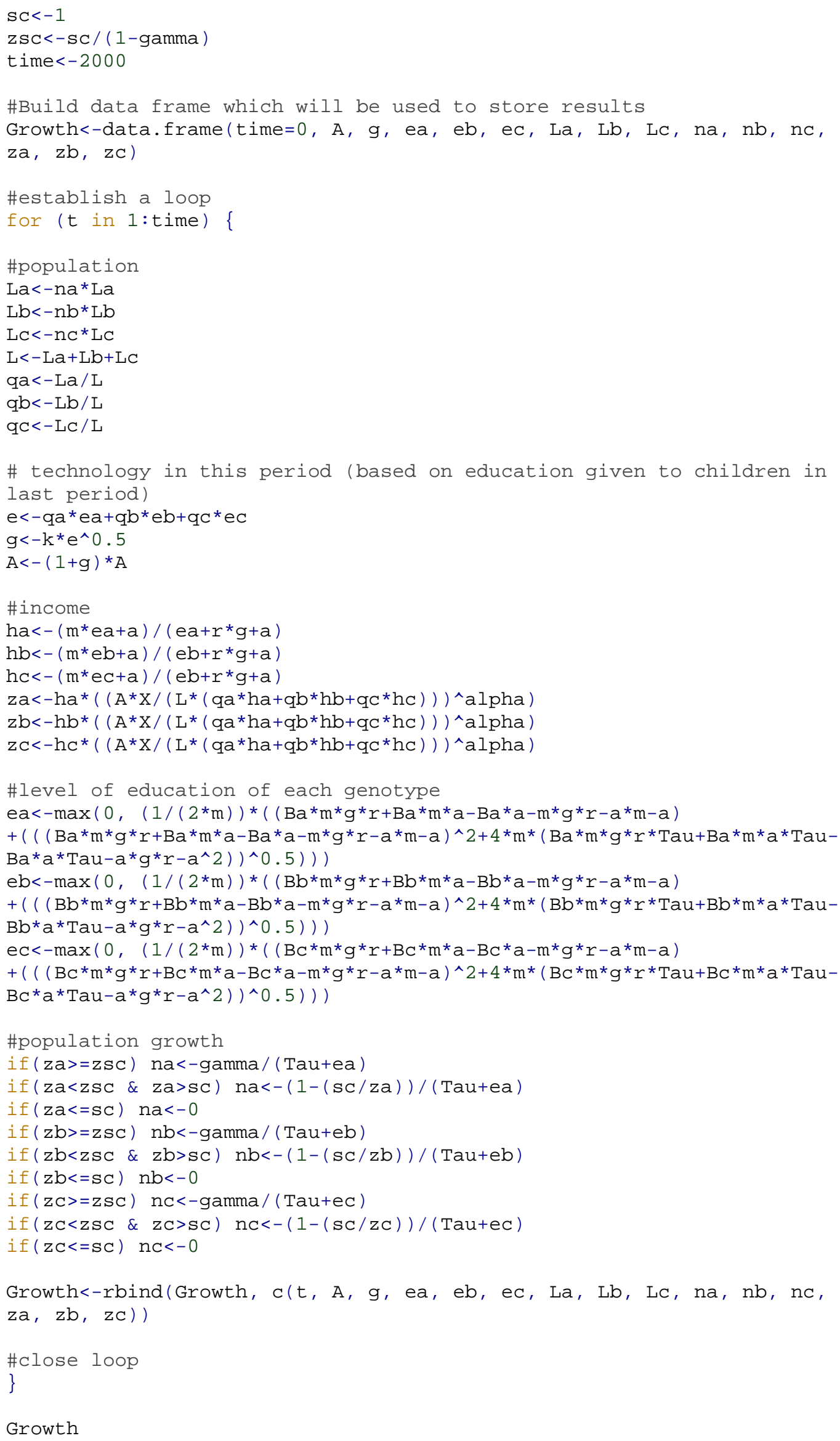




\begin{tabular}{|c|c|c|}
\hline \multicolumn{3}{|c|}{$\begin{array}{l}\text { ECONOMICS DISCUSSION PAPERS } \\
2009\end{array}$} \\
\hline DP NUMBER & AUTHORS & TITLE \\
\hline 09.01 & Le, A.T. & $\begin{array}{l}\text { ENTRY INTO UNIVERSITY: ARE THE CHILDREN OF } \\
\text { IMMIGRANTS DISADVANTAGED? }\end{array}$ \\
\hline 09.02 & $\mathrm{Wu}, \mathrm{Y}$ & $\begin{array}{l}\text { CHINA'S CAPITAL STOCK SERIES BY REGION AND } \\
\text { SECTOR }\end{array}$ \\
\hline 09.03 & Chen, M.H. & $\begin{array}{l}\text { UNDERSTANDING WORLD COMMODITY PRICES } \\
\text { RETURNS, VOLATILITY AND DIVERSIFACATION }\end{array}$ \\
\hline 09.04 & Velagic, $\mathrm{R}$. & $\begin{array}{l}\text { UWA DISCUSSION PAPERS IN ECONOMICS: THE FIRST } \\
650\end{array}$ \\
\hline 09.05 & McLure, M. & $\begin{array}{l}\text { ROYALTIES FOR REGIONS: ACCOUNTABILITY AND } \\
\text { SUSTAINABILITY }\end{array}$ \\
\hline 09.06 & Chen, A. and Groenewold, N. & $\begin{array}{l}\text { REDUCING REGIONAL DISPARITIES IN CHINA: AN } \\
\text { EVALUATION OF ALTERNATIVE POLICIES }\end{array}$ \\
\hline 09.07 & Groenewold, N. and Hagger, A. & $\begin{array}{l}\text { THE REGIONAL ECONOMIC EFFECTS OF IMMIGRATION: } \\
\text { SIMULATION RESULTS FROM A SMALL CGE MODEL. }\end{array}$ \\
\hline 09.08 & Clements, K. and Chen, D. & $\begin{array}{l}\text { AFFLUENCE AND FOOD: SIMPLE WAY TO INFER } \\
\text { INCOMES }\end{array}$ \\
\hline 09.09 & Clements, K. and Maesepp, M. & A SELF-REFLECTIVE INVERSE DEMAND SYSTEM \\
\hline 09.10 & Jones, C. & $\begin{array}{l}\text { MEASURING WESTERN AUSTRALIAN HOUSE PRICES: } \\
\text { METHODS AND IMPLICATIONS }\end{array}$ \\
\hline 09.11 & Siddique, M.A.B. & $\begin{array}{l}\text { WESTERN AUSTRALIA-JAPAN MINING CO-OPERATION: } \\
\text { AN HISTORICAL OVERVIEW }\end{array}$ \\
\hline 09.12 & Weber, E.J. & $\begin{array}{l}\text { PRE-INDUSTRIAL BIMETALLISM: THE INDEX COIN } \\
\text { HYPTHESIS }\end{array}$ \\
\hline 09.13 & McLure, M. & $\begin{array}{l}\text { PARETO AND PIGOU ON OPHELIMITY, UTILITY AND } \\
\text { WELFARE: IMPLICATIONS FOR PUBLIC FINANCE }\end{array}$ \\
\hline 09.14 & Weber, E.J. & $\begin{array}{l}\text { WILFRED EDWARD GRAHAM SALTER: THE MERITS OF } \\
\text { A CLASSICAL ECONOMIC EDUCATION }\end{array}$ \\
\hline 09.15 & Tyers, R. and Huang, L. & $\begin{array}{l}\text { COMBATING CHINA'S EXPORT CONTRACTION: FISCAL } \\
\text { EXPANSION OR ACCELERATED INDUSTRIAL REFORM }\end{array}$ \\
\hline 09.16 & $\begin{array}{l}\text { Zweifel, P., Plaff, D. and } \\
\text { Kühn, J. }\end{array}$ & $\begin{array}{l}\text { IS REGULATING THE SOLVENCY OF BANKS COUNTER- } \\
\text { PRODUCTIVE? }\end{array}$ \\
\hline 09.17 & Clements, $\mathrm{K}$. & THE PHD CONFERENCE REACHES ADULTHOOD \\
\hline 09.18 & McLure, M. & $\begin{array}{l}\text { THIRTY YEARS OF ECONOMICS: UWA AND THE WA } \\
\text { BRANCH OF THE ECONOMIC SOCIETY FROM } 1963 \text { TO } \\
1992\end{array}$ \\
\hline 09.19 & Harris, R.G. and Robertson, P. & $\begin{array}{l}\text { TRADE, WAGES AND SKILL ACCUMULATION IN THE } \\
\text { EMERGING GIANTS }\end{array}$ \\
\hline 09.20 & $\begin{array}{l}\text { Peng, J., Cui, J., Qin, F. and } \\
\text { Groenewold, N. }\end{array}$ & STOCK PRICES AND THE MACRO ECONOMY IN CHINA \\
\hline 09.21 & Chen, A. and Groenewold, N. & $\begin{array}{l}\text { REGIONAL EQUALITY AND NATIONAL DEVELOPMENT } \\
\text { IN CHINA: IS THERE A TRADE-OFF? }\end{array}$ \\
\hline
\end{tabular}




\section{ECONOMICS DISCUSSION PAPERS}

2010

\begin{tabular}{|c|c|c|}
\hline $\begin{array}{l}\text { DP } \\
\text { NUMBER }\end{array}$ & AUTHORS & TITLE \\
\hline 10.01 & Hendry, D.F. & $\begin{array}{l}\text { RESEARCH AND THE ACADEMIC: A TALE OF } \\
\text { TWO CULTURES }\end{array}$ \\
\hline 10.02 & McLure, M., Turkington, D. and Weber, E.J. & A CONVERSATION WITH ARNOLD ZELLNER \\
\hline 10.03 & $\begin{array}{l}\text { Butler, D.J., Burbank, V.K. and } \\
\text { Chisholm, J.S. }\end{array}$ & $\begin{array}{l}\text { THE FRAMES BEHIND THE GAMES: PLAYER'S } \\
\text { PERCEPTIONS OF PRISONER'S DILEMMA, } \\
\text { CHICKEN, DICTATOR, AND ULTIMATUM } \\
\text { GAMES }\end{array}$ \\
\hline 10.04 & $\begin{array}{l}\text { Harris, R.G., Robertson, P.E. and } \\
\text { Xu, J.Y. }\end{array}$ & $\begin{array}{l}\text { THE INTERNATIONAL EFFECTS OF CHINA'S } \\
\text { GROWTH, TRADE AND EDUCATION BOOMS }\end{array}$ \\
\hline 10.05 & Clements, K.W., Mongey, S. and Si, J. & $\begin{array}{l}\text { THE DYNAMICS OF NEW RESOURCE } \\
\text { PROJECTS A PROGRESS REPORT }\end{array}$ \\
\hline 10.06 & Costello, G., Fraser, P. and Groenewold, N. & $\begin{array}{l}\text { HOUSE PRICES, NON-FUNDAMENTAL } \\
\text { COMPONENTS AND INTERSTATE } \\
\text { SPILLOVERS: THE AUSTRALIAN EXPERIENCE }\end{array}$ \\
\hline 10.07 & Clements, $\mathrm{K}$. & $\begin{array}{l}\text { REPORT OF THE } 2009 \text { PHD CONFERENCE IN } \\
\text { ECONOMICS AND BUSINESS }\end{array}$ \\
\hline 10.08 & Robertson, P.E. & $\begin{array}{l}\text { INVESTMENT LED GROWTH IN INDIA: HINDU } \\
\text { FACT OR MYTHOLOGY? }\end{array}$ \\
\hline 10.09 & Fu, D., Wu, Y. and Tang, Y. & $\begin{array}{l}\text { THE EFFECTS OF OWNERSHIP STRUCTURE } \\
\text { AND INDUSTRY CHARACTERISTICS ON } \\
\text { EXPORT PERFORMANCE }\end{array}$ \\
\hline 10.10 & Wu, Y. & $\begin{array}{l}\text { INNOVATION AND ECONOMIC GROWTH IN } \\
\text { CHINA }\end{array}$ \\
\hline 10.11 & Stephens, B.J. & $\begin{array}{l}\text { THE DETERMINANTS OF LABOUR FORCE } \\
\text { STATUS AMONG INDIGENOUS AUSTRALIANS }\end{array}$ \\
\hline 10.12 & Davies, M. & $\begin{array}{l}\text { FINANCING THE BURRA BURRA MINES, } \\
\text { SOUTH AUSTRALIA: LIQUIDITY PROBLEMS } \\
\text { AND RESOLUTIONS }\end{array}$ \\
\hline 10.13 & Tyers, R. and Zhang, Y. & APPRECIATING THE RENMINBI \\
\hline 10.14 & Clements, K.W., Lan, Y. and Seah, S.P. & $\begin{array}{l}\text { THE BIG MAC INDEX TWO DECADES ON } \\
\text { AN EVALUATION OF BURGERNOMICS }\end{array}$ \\
\hline 10.15 & Robertson, P.E. and Xu, J.Y. & $\begin{array}{l}\text { IN CHINA'S WAKE: } \\
\text { HAS ASIA GAINED FROM CHINA'S GROWTH? }\end{array}$ \\
\hline 10.16 & Clements, K.W. and Izan, H.Y. & $\begin{array}{l}\text { THE PAY PARITY MATRIX: A TOOL FOR } \\
\text { ANALYSING THE STRUCTURE OF PAY }\end{array}$ \\
\hline 10.17 & Gao, G. & WORLD FOOD DEMAND \\
\hline 10.18 & Wu, Y. & $\begin{array}{l}\text { INDIGENOUS INNOVATION IN CHINA: } \\
\text { IMPLICATIONS FOR SUSTAINABLE GROWTH }\end{array}$ \\
\hline 10.19 & Robertson, P.E. & DECIPHERING THE HINDU GROWTH EPIC \\
\hline 10.20 & Stevens, G. & $\begin{array}{l}\text { RESERVE BANK OF AUSTRALIA-THE ROLE OF } \\
\text { FINANCE }\end{array}$ \\
\hline
\end{tabular}




\begin{tabular}{|l|l|l|}
\hline 10.21 & Widmer, P.K., Zweifel, P. and Farsi, M. & $\begin{array}{l}\text { ACCOUNTING FOR HETEROGENEITY IN THE } \\
\text { MEASUREMENT OF HOSPITAL PERFORMANCE }\end{array}$ \\
\hline 10.22 & McLure, M. & $\begin{array}{l}\text { ASSESSMENTS OF A. C. PIGOU'S FELLOWSHIP } \\
\text { THESES }\end{array}$ \\
\hline 10.23 & Poon, A.R. & $\begin{array}{l}\text { THE ECONOMICS OF NONLINEAR PRICING: } \\
\text { EVIDENCE FROM AIRFARES AND GROCERY } \\
\text { PRICES }\end{array}$ \\
\hline 10.24 & Halperin, D. & $\begin{array}{l}\text { FORECASTING METALS RETURNS: A } \\
\text { BAYESIAN DECISION THEORETIC APPROACH }\end{array}$ \\
\hline 10.25 & Clements, K.W. and Si. J. & $\begin{array}{l}\text { THE INVESTMENT PROJECT PIPELINE: COST } \\
\text { ESCALATION, LEAD-TIME, SUCCESS, FAILURE } \\
\text { AND SPEED }\end{array}$ \\
\hline 10.26 & $\begin{array}{l}\text { Chen, A., Groenewold, N. and Hagger, A.J. } \\
\text { THE REGIONAL ECONOMIC EFFECTS OF A }\end{array}$ \\
\hline 10.27 & $\begin{array}{l}\text { REDUCTION IN CARBON EMISSIONS } \\
\text { Siddique, A., Selvanathan, E.A. and }\end{array}$ & $\begin{array}{l}\text { REMITTANCES AND ECONOMIC GROWTH: } \\
\text { EMPIRICAL EVIDENCE FROM BANGLADESH, } \\
\text { INDIA AND SRI LANKA }\end{array}$ \\
\hline
\end{tabular}




\begin{tabular}{|c|c|c|}
\hline \multicolumn{3}{|c|}{$\begin{array}{l}\text { ECONOMICS DISCUSSION PAPERS } \\
2011\end{array}$} \\
\hline $\begin{array}{l}\text { DP } \\
\text { NUMBER }\end{array}$ & AUTHORS & TITLE \\
\hline 11.01 & Robertson, P.E. & $\begin{array}{l}\text { DEEP IMPACT: CHINA AND THE WORLD } \\
\text { ECONOMY }\end{array}$ \\
\hline 11.02 & Kang, C. and Lee, S.H. & $\begin{array}{l}\text { BEING KNOWLEDGEABLE OR SOCIABLE? } \\
\text { DIFFERENCES IN RELATIVE IMPORTANCE OF } \\
\text { COGNITIVE AND NON-COGNITIVE SKILLS }\end{array}$ \\
\hline 11.03 & Turkington, D. & DIFFERENT CONCEPTS OF MATRIX CALCULUS \\
\hline 11.04 & Golley, J. and Tyers, R. & $\begin{array}{l}\text { CONTRASTING GIANTS: DEMOGRAPHIC CHANGE } \\
\text { AND ECONOMIC PERFORMANCE IN CHINA AND } \\
\text { INDIA }\end{array}$ \\
\hline 11.05 & Collins, J., Baer, B. and Weber, E.J. & $\begin{array}{l}\text { ECONOMIC GROWTH AND EVOLUTION: } \\
\text { PARENTAL PREFERENCE FOR QUALITY AND } \\
\text { QUANTITY OF OFFSPRING }\end{array}$ \\
\hline 11.06 & Turkington, D. & $\begin{array}{l}\text { ON THE DIFFERENTIATION OF THE LOG } \\
\text { LIKELIHOOD FUNCTION USING MATRIX } \\
\text { CALCULUS }\end{array}$ \\
\hline 11.07 & Groenewold, N. and Paterson, J.E.H. & $\begin{array}{l}\text { STOCK PRICES AND EXCHANGE RATES IN } \\
\text { AUSTRALIA: ARE COMMODITY PRICES THE } \\
\text { MISSING LINK? }\end{array}$ \\
\hline 11.08 & Chen, A. and Groenewold, N. & $\begin{array}{l}\text { REDUCING REGIONAL DISPARITIES IN CHINA: IS } \\
\text { INVESTMENT ALLOCATION POLICY EFFECTIVE? }\end{array}$ \\
\hline 11.09 & Williams, A., Birch, E. and Hancock, P. & $\begin{array}{l}\text { THE IMPACT OF ON-LINE LECTURE RECORDINGS } \\
\text { ON STUDENT PERFORMANCE }\end{array}$ \\
\hline 11.10 & Pawley, J. and Weber, E.J. & $\begin{array}{l}\text { INVESTMENT AND TECHNICAL PROGRESS IN THE } \\
\text { G7 COUNTRIES AND AUSTRALIA }\end{array}$ \\
\hline
\end{tabular}

